NBER Working Paper \#4890

October 1994

\title{
MARKET TIMING ABILITY AND \\ VOLATILITY IMPLIED IN \\ INVESTMENT NEWSLETTERS' ASSET \\ ALLOCATION RECOMMENDATIONS
}

\begin{abstract}
We analyze the advice contained in a sample of 237 investment letters over the 1980-1992 period. Each newsletter recommends a mix of equity and cash. We construct portfolios based on these recommendations and find that only a small number of the newsletters appear to have higher average returns than a buy-and-hold portfolio constructed to have the same variance. Knowledge of the asset allocation weights also implies knowledge of the exact conditional betas. As a result, we present direct tests of market timing ability that bypass beta estimation problems. Assuming that different letters cater to investors with different risk aversions, we are able to imply the newsletters' forecasted market returns. The dispersion of the newsletters' forecasts provides a natural measure of disagreement in the market. We find that the degree of disagreement contains information about both market volatility and trading activity.
\end{abstract}

John R. Graham

Deparment of Economics

University of Utah

Salt Lake City, UT 84112
Campbell R. Harvey

Fuqua School of Business

Duke University

Durham, NC 27708

and NBER 


\section{Introduction}

Student: Do investment newsletters have any value?

Professor: You get what you pay for.

Sound familiar? There are hundreds maybe thousands of investment newsletters. Most of us, at some point in time, have been asked to recommend or give a general opinion on the value of investment newsletters. The authors of these newsletters often play a prominent role in the media. Given the sizable subscription base, a number of investors appear to value these services.

Our paper is the first effort analyze the information contained in investment newsletters. We evaluate the performance of 237 newsletters from June 1980 to December 1992. These newsletters recommend investment weights for cash and equity. That is, rather than concentrating on specific equity recommendations, these newsletters' attempt to call the direction of the market as a whole. ${ }^{1}$

Our work provides an interesting contrast to the work on mutual fund performance evaluation. Indeed, our tests have two important advantages over the mutual fund studies. First, our portfolios are simple (equity and cash) and we can construct portfolios that exactly mimic the newsletters' recommendations. Transactions costs are born by the investor (the only management fee is the subscription price). Many investors might choose to manage the recommendations by trading in the Standard and Poor's 500 futures contract along with a money market deposit to minimize transactions costs.

With mutual funds, it is impossible to replicate holdings. Grinblatt and Titman (1989), for example, expend painstaking effort to collect the end-of-quarter holdings of over 500 mutual funds at the Security and Exchange Commission. This allows them to construct passive portfolios of the same equities held by the

1 There are a number of studies that focus on the stock picking ability of analysts, see for example, Bjerring, Lakonishok and Vermaelen (1983), Dimson and Marsh (1984), Groth, Lewellen, Schlarbaum and Lease (1979), Elton, Gruber and Grossman (1986) and Womack (1994). 
mutual fund and to estimate the transactions costs that the funds incur. This is an important study, however, the end-of-quarter holdings may not accurately reflect mutual fund activity within a quarter.

The second advantage of our newsletter sample is that it does not suffer from some of the acute survivorship biases that plague many previous mutual fund studies [see Brown, Goetzmann, Ibbotson and Ross (1992)]. Even a number of recent studies of performance evaluation such as Ferson and Schadt (1994), Chen and Knez (1993) and Bansal and Harvey (1994) use long samples of monthly data of mutual fund survivors. That is, to be included in the sample, these papers require that the fund has survived for at least 22 years. If such a rule were used in our study, we would be left with only 13 of the 237 newsletters.

We investigate a number of interesting issues. Given our knowledge of the investment weights, our study analyzes the market timing abilities of the newsletters. We investigate whether recommended equity weights increase before the market rises. In addition, if we assume that there is common knowledge of timevarying expected returns, we test whether the investment recommendations add anything beyond the common expected returns. We define extra market timing ability as correctly anticipating the direction of the market when the economywide expectation about the direction of the market is incorrect.

The second interesting issue concerns the information in the newsletters' forecasts. While the newsletters only provide asset weights, we imply the expected returns by assuming an exponential utility function. We allow risk aversion to differ across newsletters - but assume that risk aversion is constant through time. We form mean and median newsletter market forecasts and investigate how these forecasts relate to the expected returns implied by a statistical model. We also investigate a weighting scheme that rewards good past forecasting performance by lowering the weight on past poor performance in developing a consensus forecast.

Finally, we explore the information in the dispersion of newsletter forecasts. Is more disagreement associated with higher volatility and volume? To this end, we test whether changes in dispersion are related to changes in both future realized volatility and future implied volatility from options prices. 
Our results indicate that fewer than $25 \%$ of the investment letters achieve returns greater than a volatility-matched buy-and-hold equity/cash portfolio. In addition, the newsletters' ability to time the market is unimpressive. It is rare that the equity allocation weights increase before the market goes up and the economy wide expectation of market returns is negative. This suggests that, in most cases, investment letters do not provide any information over and above that which is publicly available. Consistent with mutual fund studies, we detail significant persistence in investment letter performance. Past performance is a predictor of future performance. However, past performance is almost always poor.

When we imply the aggregate forecasted market returns, we find that these predictions have little information about future returns. While the magnitude of forecast is not that informative, the standard deviation is important. We present evidence that the dispersion of the investment letter forecasts Granger causes future volatility, future implied volatility and future trading volume.

Our paper is organized as follows. The second section details the nature of the data and provides some summary statistics. Direct measures of market timing are investigated in the third section. This section also presents the tests of persistence in the investment letter performance. The fourth section presents an analysis of the relation between forecast dispersion, volume and volatility. Some concluding remarks are offered in the final section.

\section{The data}

\subsection{Sources}

We have data, provided by Source, ${ }^{2}$ on 237 newsletters over the 13 years ending in December 1992. Source collects data on a comprehensive sample of newsletters and compiles data on the ones that provide concrete recommendations. Each observation satisfies the restriction that long+short+cash-margin $=100 \%$. The date an observation is added to the raw file is the date Source receives it in the

\footnotetext{
2 The name of Source will be revealed before publication of this research.
} 
mail - rather than the date published on the newsletter. Our data has essentially no survivorship bias problem because funds are added on the day Source first receives the letter; no data are deleted when a newsletter ceases to exist.

There are 15,172 total recommendations (across all newsletters). This actually overstates the number of observations to a small degree because Source always imputes a year-end and year-beginning forecast for every newsletter in existence. even if their forecast did not change between, say, November 1990 and February 1991. The first observation for any newsletter is in June 1980; the last possible observation is December 1992. Thirteen newsletters exist for the entire sample.

In the raw data, an observation can occur on any day during a month, and multiple observations may occur in any month. However, for our tests, we will concentrate on monthly recommendations. This allows us to link our work with the growing literature on conditional performance measurement - which uses monthly data. To this end, we use the last observation in a month as our "monthly" asset weight recommendation. ${ }^{3}$ We also "add" observations for months in which a newsletter exists, but did not change its forecast. For example, if a newsletter provides only a January forecast in a particular year, we assign twelve monthly observations. These additions should not bias the newsletters' performances. If recommendations are made quarterly, it is reasonable to assume that the portfolio weights are constant over the three months of the quarter. We do, however, make one exception to the addition rule. If a letter explicitly withdraws a previous forecast without making a new forecast, we do not carry forward the old forecasts. The net result of our deletion of intramonth recommendations and our addition of recommendations leaves us with 15,133 observations.

Source may "clarify" the data if a newsletter is vague in its recommendations. For example, if a newsletter is $50 \%$ long the market and $50 \%$ in cash, but recommends a one-month hedge against the long, Source may impute a $50 \%$ short-in-futures-market with a 50\% margin; this hedges the long position but avoids transaction costs for closing out the long position. For consistency across

${ }^{3}$ Later in the paper, we assess the sensitivity our results to this simplifying assumption by acting on the recommendation the day the investment letter is received using the daily S\&P 500 returns. 
our data, however, in situations where both long and short positions are greater than zero we take the net position and assign the remainder to cash. In the previous example, we would classify the fund $100 \%$ cash. We assume that the cash instrument return is the 30-day Treasury bill rate.

Newsletters can recommend a margin position, for example, $200 \%$ long in the market. In such a case, the letter earns twice the market return minus the margin-rate. The margin-rate is provided is also provided by Source.

We have not restricted any fund to a maximum long position of 200, although security regulations do impose this restriction. Indeed, we will see that one fund often recommends long positions much greater than 200. A short return is simply the opposite of the market return for the month.

We assume that round-trip transactions costs are 1 percent. So, for example, if a newsletter is long $80 \%$ one month and long $20 \%$ the following month (and initially cash $20 \%$ and then cash $80 \%$ ), transaction costs are $.005 \times(80-20) / 100$ for the second month. This level of transactions costs is attainable by discount brokers and is conservative if one elects to manage the newsletter portfolios using the S\&P 500 futures. There are also a number of mutual funds that allow investors to switch (at no charge for the switch) between the family of funds once a month.

\subsection{Summary statistics and nonparametric evaluation}

Table 1 presents the preliminary analysis of the newsletter performance, with and without transactions costs. The first entry is not a newsletter but the statistical forecasting model presented in Harvey (1989). This model was originally fit over 1959-1986 ${ }^{4}$ and uses the following instrumental variables to forecast the market return: the lagged excess return on the CRSP NYSE equally-weighted index, the lagged excess return on a 3-month Treasury bill, the lagged Moody's Baa-Aaa yield

4 We are sensitive to the issue of data snooping. The original paper, submitted to the Western Finance Association program on November 24, 1987, used data from February 1959-December 1986. The published version of the article extended the data back to 1941 and forward to December 1987. 
spread, the lagged excess dividend yield on the S\&P 500 index, and a January dummy variable. While there is some danger that the statistical model has been overfit, all forecasts beginning in January 1987 are out of sample.

The benchmark statistical model return is formed as follows. A linear regression model is estimated with the stock market returns through time $t$ and information variables through time $t-1$. The estimated coefficients are applied to the information variables at time $t$ to forecast the market return in $t+1$. If the forecasted market return is above the known 30-day Treasury bill rate, then a $100 \%$ market position is formed. If the forecasted return is less than the bill rate. then a 100\% cash position is initiated. At the end of each month, the regression model's parameters are reestimated and new forecasts are calculated.

In terms of mean-variance analysis, the idea of the strategy is to be on the positively sloping portion of the mean-variance frontier which includes only two assets. Conditionally, the frontier looks like a sideways "V." The 30-day Treasury bill has exactly zero conditional variance because next month's return is determined by the discount from par value. Any time the expected excess market return is negative, all the allocation goes to the bill. ${ }^{5}$ This strategy will almost always result in a volatility less than or equal to the volatility of the market return. ${ }^{6}$ We also report the forecasts implied by an equally-weighted portfolio of all of the newsletter portfolios and an equally-weighted portfolio with newsletters in existence for more than four years.

First, consider the unconditional performance of the statistical model. Over

${ }^{5}$ There are a number of variants of this strategy which we did not pursue. One simple refinement is to place a filter on the market entries. That is, if the forecasted market return is only a few basis points above the forecasted equity return, it does not make sense to enter the risky market and incur the transactions costs. One could also allow for short positions if the forecasted market return is negative. A further refinement would be to impose a constant level of risk aversion over the sample which would lead to mixed cash and equity positions. We chose to pursue the simplest possible strategy; the act of refining the statistically based strategy may lead to another level of data snooping.

${ }^{6}$ It is possible that frequent switching from cash to equity could induce more volatility that an equity buy and hold. However, this possibility only exists if the volatility of the equity returns is very small - which is not the case in our sample. 
the entire period, the average performance before (after) transactions costs was $17.1 \%(15.4 \%)$ per annum. The return to a buy-and-hold strategy of the S\&P 500 cash index over the same period produced $15.9 \%$ (15.8\%) per annum on average. However, the volatility of the statistical model's portfolio is $12.4 \%$ compared to $15.9 \%$ for the S\&P buy-and-hold strategy. Over the same period, an equally weighted portfolio of all the newsletter portfolios produced a $11.3 \%(10.9 \%)$ average return with an $8.4 \%$ volatility.

While it is clear that the statistical model unconditionally dominates (higher mean and lower variance, in a two moment framework) the S\&P buy-and-hold strategy before transactions costs, these numbers are difficult to interpret. As a result, we provide two nonparametric measures of performance. These simple measures are nonparametric in the sense that no asset pricing model has been imposed. The metrics are designed to compare the newsletter performance with the fixed investment weight equity/cash strategy on the basis of the same volatility.

In our first measure, we lever a S\&P 500 portfolio up or down in order to set its unconditional volatility equal to the unconditional volatility of the newsletter portfolio return over matching samples. For example, if the newsletter volatility was $8 \%$, a portfolio of approximately $50 \%$ cash and $50 \%$ equity (assuming the S\&P 500 volatility is $16 \%$ ) with the weights held constant in every month, is constructed to mimic the active newsletter portfolio's volatility. The difference between the returns on the newsletter portfolio and the constructed portfolio provides a measure of abnormal return. ${ }^{7}$ While this gives us a nonparametric measure of performance for the newsletter, it is still difficult to compare across newsletters. For example, most would consider a $1 \%$ annual abnormal return for a $8 \%$ volatility newsletter portfolio more impressive than a $1.1 \%$ annual abnormal return for a $16 \%$ volatility newsletter portfolio.

Our second measure addresses the comparability issue. We lever the newsletter portfolio strategy to have the same volatility as the $100 \%$ S\&P 500 buyand-hold strategy over matching samples. For example, we would transform the

7 The levered buy-and-hold portfolio is not a passive portfolio. That is, to keep the constant asset weights some rebalancing is necessary each month. We subtract the transactions costs associated with rebalancing in calculating the returns. 
newsletter portfolio to have $15.9 \%$ average volatility if the newsletter existed for the full sample period. ${ }^{8}$ The difference between the newsletter portfolio return and the S\&P return provides a natural measure of "abnormal" returns, where abnormal is defined in the context of the S\&P 500 benchmark. ${ }^{9}$

The statistical model provides 110 basis points more return after transactions costs than the unlevered S\&P 500 return portfolio with volatility set at $12.4 \%$ (measure 1, Table 1, column 7). When the statistical model is levered to produce $15.9 \%$ volatility (same as the S\&P 500), it provides $140 \mathrm{bp}$ extra annual-return after transactions costs (measure 2, Table 1, column 8 ). The statistical model provides $370 \mathrm{bp}$ and $630 \mathrm{bp}$ extra return for these two measures, respectively, over the period 1987 to 1992, which is out-of-sample from the original Harvey (1989) analysis. ${ }^{10}$

The equally-weighted newsletter portfolio does not fare well by our two nonparametric measures. The newsletter portfolio provides $150 \mathrm{bp}$ lower return than the S\&P when the cash/equity volatility is set to $8.4 \%$. The levered newsletter portfolio delivers $420 \mathrm{bp}$ less return when its volatility is increased to $15.9 \%$.

An examination of the results for individual newsletters shows dramatic differences in performance. One of the highest profile letters, the Granville Market Letter-Traders Portfolio, lost $5.4 \%$ per annum over the past 13 years. The $Z$ weig - Short-term Trend Indicator (with shorting) forecast has lost $6.8 \%$ per year since 1984. The Elliott Wave Theorist-Traders lost $14.8 \%$ per year since December 1985.

8 We solve for $w$ such that $\sigma_{S P}^{2}=w^{2} \sigma_{L e t}^{2}+(1-w)^{2} \sigma_{T B}^{2}+2 w(1-w) \operatorname{Cov}\left[R_{L e t}, R_{T B}\right]$, where $S P$ represents the Standard and Poor's 500 cash index, TB is the 30 -day Treasury bill, and Let is the investment newsletter portfolio.

9 Measure 2 is similar to a Sharpe ratio which tells the amount of expected return per unit of volatility.

10 This performance is obviously influenced by the crash observation. The statistical model correctly forecasts a negative excess return for October 1987 which takes the portfolio of the market. This increases the average annual returns by $320 \mathrm{bp}$ and lowers the volatility. Omitting this observation, the measure 1 and 2 abnormal returns are $110 \mathrm{bp}$ and $180 \mathrm{bp}$, respectively. These are consistent with the results for the full sample. 
There are impressive individual performances also. Bob Nurock's AdvisoryTMI-(no shorting) produced annual returns of $22.5 \%$ per year from $1980 .{ }^{11}$ The Medical Technology Stock Letter delivered $29.7 \%$ annual returns since December 1985. The Fidelity Monitor produced $24.7 \%$ per year since December 1986. However, most letters produce negative abnormal profits according to the two nonparametric measures. 200 of 237 (84.4\%) of the letters produced negative abnormal returns when compared to the cash/equity strategy with equal volatility (Table 1, column 7 ). 183 of 237 (77.3\%) of the letters also produced negative abnormal returns when the newsletter portfolios were levered to have the same volatility as the S\&P 500 (Table 1, column 8). ${ }^{12}$

Although the paper is based on monthly data, we assessed the implication of our assigning end-of-month recommendations to newsletters that produced recommendations before the end of the month. Using daily S\&P 500 data, the measures in table 1 were replicated for a random sample of newsletters. The average performance metrics based on the daily data were similar to the monthly averages.

A visual presentation of the data is contained in Figure 1. Panel A presents the average returns and volatilities measured over the full sample that each newsletter portfolio is available. That is, the points on the graph represent the unconditional mean and standard deviation of the newsletter strategies (which are potentially calculated over different time periods). There is one distinct outlier, the Wall Street Generalist, which has a volatility of $60.8 \%$ (and is omitted from the graph). Overlaid on this graph is the unconditional performance of the statistical model (diamond), the equally-weighted newsletter return (circle) and the S\&P portfolio calculated over the full sample (star). Immediately below, in panel $\mathrm{C}$, is the same graph with the data subset from January 1987. This provides a more meaningful comparison with the statistical model's out-of-sample forecasts. This graph is very similar to the one in panel A. The performance of the statistical

11 However, Bob Nurock has seven letters in the database. Bob Nurock's Advisory, in contrast to $T M I$, has on average lost $11.8 \%$ per year since inception.

12 The percentages, $84.4 \%$ and $77.3 \%$, need not be the same for the two measures. With sufficient variance, measure 1 could be negative and measure 2 could be positive. 
model improves and the equally-weighted newsletter deteriorates moving from one sample to the next.

The final panels of Figure 1 select only the newsletters that make recommendations for more than four years. We impose this selection criteria because, later in the paper, we need to infer the newsletter's average taste for risk. We believe that a meaningful estimate of risk aversion should span at least the average length of the business cycle, which is about four years in our sample. However, the fouryear rule could induce a survivorship bias. It also eliminates all newsletters that entered the database after January 1989. Interestingly, the performance of this sample is similar to the uncensored sample. From Table 1, the average uncensored newsletter return is $10.9 \%$ with a volatility of $8.4 \%$. The censored sample has an average return of $10.7 \%$ and a volatility of $8.1 \%$. Comparing panels $\mathrm{A}$ and $\mathrm{B}$ of Figure 1, many of the highest mean return newsletters as well as the lowest mean return newsletters are omitted with the four year rule.

Figure 2 summarizes the nonparametric performance of the newsletter portfolios. First, both the abnormal measures give similar results with about $20 \%$ of the newsletter portfolios falling in the positive range. Second, the distribution of performance is skewed towards poor performance. Third, there are no obvious effects from imposing the four year rule for sampling - the distribution of performance appears quite similar.

\section{Assessing market timing abilities}

\subsection{Traditional timing measures}

The literature on evaluation of mutual fund managers tries to measure two aspects of performance: the ability to pick stocks and the ability to time the market. The first aspect is not relevant to our study since the investment letters recommend positions in only two broad asset classes. One of the goals of the paper is to determine whether the newsletters have any ability to call the direction of the market (or time the market). 
A number of studies have tried to both allow for the possibility of market timing and to measure its effectiveness. Treynor and Mazuy (1966) proposed a quadratic regression:

$$
r_{i t}=\alpha^{T M}+\beta_{i}^{T M} r_{m t}+\gamma_{i}^{T M} r_{m t}^{2}+\epsilon_{i t}^{T M}
$$

Successful market timing would be indicated if $\gamma_{i}^{T M}>0$. This implies that the beta of the portfolios increases when the market return is large in absolute value. Merton (1981) and Merton and Henriksson (1981) propose an alternative model where the linear regression is augmented with a slope dummy variable.

$$
r_{i t}=\alpha^{M H}+\beta_{i}^{M H} r_{m t}+\gamma_{i}^{M H} I\left(r_{m t}^{+}\right) \times r_{m t}+\epsilon_{i t}^{M H},
$$

where $I\left(r_{m t}^{+}\right)$is an indicator variable that is on if the market return is positive. This nonlinearity is of the piece-wise form (compared to the previous quadratic form) and Merton and Henriksson give an option interpretation to market timing. Successful market timing implies that $\gamma_{i}^{M H}>0$.

Market timing involves a shifting of the individual stocks within the portfolio. However, the response of the manager may vary depending upon the economic signals she receives. While the Treynor-Mazuy (1966) and the Merton-Henriksson (1981) models capture some nonlinearity in the risk, the functional form may be too rigid.

Ferson and Schadt (1994) offer an important innovation in performance measurement. They introduce time-varying conditional betas in both of the standard models to allow the manager's portfolio response to be a function of economic conditions. The beta is assumed to be a linear function of lagged economy-wide information variables. This allows Ferson and Schadt to test whether managers are altering their portfolio mix with economy-wide information and to isolate the information which has the most impact on portfolio rebalancing. They also propose tests to determine whether managers use information over and above the assumed market information in setting their market mix. 


\subsection{A direct measure of market timing}

One advantage to our newsletter sample is that we do not need to estimate the conditional betas. That is, given that we know the weights, we know the conditional beta exactly. For example, a newsletter with a $100 \%$ market equity weight has a beta of 1.0. Since we assume that the cash instrument is the 30-day Treasury bill, a $100 \%$ in cash position implies the conditional beta is 0.0 . Hence, we bypass any estimation error in the risk estimates and we do not have to worry about issues relating to whether the market portfolio is mean-variance efficient.

We can directly model market timing ability by estimating the model:

$$
r_{m, t+1}=\delta_{i, 1}+\delta_{i, 2} \Delta w_{i, t}+\delta_{i}^{\prime} Z_{t}+\epsilon_{i, t+1}
$$

where $\Delta w_{i t}$ represents the change in net equity position at the end of month $t$, and $Z_{t}$ is a set of common information variables available at time $t$. If the coefficient $\delta_{i 2}>0$, this means that on average the newsletter is increasing (decreasing) equity weights before the market excess return is positive (negative).

The model in (3) focusses on the actions taken by the portfolio manager rather than on the actual position. For example, a reduction in equity from $100 \%$ to $50 \%$ when the market subsequently decreased is considered to be positive market timing ability. However, this does not imply the final position was optimal in any sense. Indeed, in this example, it would have been better to shift the weight by $200 \%$ rather than $50 \%$. To help address the level issue, we estimate a model identical to (3) using the demeaned levels of $w_{i t}$ as an explanatory variable. This tells us whether the portfolio has a higher (lower) equity weight, relative to its average weight, when the market return increases (decreases).

We also investigate differential abilities to time the market in up and down states. We segment (3) and run separate estimations for negative and positive market returns. In addition, we run an indicator regression, inspired by MertonHenriksson (1981), that allows us to measure differential responses:

$$
\Delta w_{i t}=\delta_{i 2} I\left(r_{m, t+1}^{+}\right)+\delta_{i 3} I\left(r_{m, t+1}^{-}\right)+\epsilon_{i, t+1},
$$

where $I(\cdot)$ is the same type of indicator variable as in (2). Notice that the market return is omitted from this regression. Essentially, (4) tells us the average increase 
(decrease) in equity weights when the market rises (falls). For reasons discussed previously, an alternate to (4) with the demeaned $w_{i t}$ as the dependent variable is also estimated in order to focus on the actual position of the newsletter.

The results of estimating (3) and (4) for each newsletter are presented in Table 2. There is no statistically significant evidence of market timing for newsletters as a group. The first panel shows the coefficient on the weight variable is positive, albeit insignificantly so, for the pooled regression. A positive coefficient indicates that equity weights are increasing (decreasing) before the future market return is positive (negative). However, newsletter by newsletter, the coefficient is positive for only $46.5 \%$ of the portfolios.

The second and third panel present results of estimating (3) separately on positive and negative market returns. Equity investment weights increase before market upturns for $58.1 \%$ of the letters. However, in the pooled regression, the coefficient is not significantly different from zero. However, equity weights also increase before market downturns for $53.1 \%$ of the letters. Similar to the upmarket regression, the pooled coefficient is not significantly different from zero.

The indicator variable specification in (4) presents similar results. In the pooled regression, the point estimates of the coefficients suggest that market weights decrease by 0.03 before positive market returns and increase by 0.11 before negative market returns. However, neither of these coefficients are statistically different from zero. Of the individual investment letters, $42.5 \%$ increased weights before positive returns and $42.3 \%$ decreased weights before negative returns.

Similar results are obtained when the demeaned values of the investment weights are used as the dependent variable. In (3), the coefficient is negative in the pooled regression which is the incorrect sign. Furthermore, for the individual investment letters only $36.1 \%$ of the sample had positive coefficients. The results for (4) are also unfavorable for the letters: only $37.3 \%$ of the portfolios had equity weights above normal before the market rose and $36.8 \%$ had equity weights below normal before the market declined. Again, neither of the coefficients are different from zero at conventional levels. 


\subsection{Market timing and conditioning information}

Market timing implies an investor has the ability to earn "abnormal" returns. Of course, one difficulty comes in the definition of abnormal. Most market timing studies have been executed within the paradigm of constant risk (for the underlying securities) and constant risk premiums. Viewed within the context of these assumptions, the statistical model produces $140 \mathrm{bp}$ abnormal return. That is, the portfolio return implied by the statistical model's forecasts which has the same volatility as the S\&P 500 buy-and-hold, delivers $140 \mathrm{bp}$ return over and above the S\&P 500 buy-and-hold strategy

However, most would not consider the statistical model's performance abnormal. Some predictable variation in returns is expected. That is, if we move away from the constant risk/constant risk premium framework, predictability in returns may naturally arise. Indeed, Ferson and Harvey (1991) show that $85 \%$ of the predictability in U.S. portfolio returns can be explained by time-varying risks and risk premiums. They show that risk premiums are high near business cycle troughs and low near business cycle peaks. As a result, it is important that our market timing tests allow for some natural degree of predictability. In (3), common information variables enter the regression. Nevertheless, we would like to be more precise about the nature of market timing.

There is some controversy, however, as to whether the time-variation in the expected returns is genuine or an artifact of data snooping (see discussions in Lo and MacKinlay (1990), Foster and Smith (1994) and Black (1993)]. We do not purport to resolve this controversy. However, as mentioned earlier, we have taken special care to make sure that the statistical model is analyzed based on an out-of-sample fit beginning in January 1987.

We measure the timing skill over and above the common level of timing inherent in the base-line predictability. Extra timing skill is evident if market weights increase before future positive market returns and common expected returns are negative. Similarly, successful timing is indicated if market weights decrease when future returns are negative and the common expected returns are positive. The 
former scenario implies that the common knowledge expectation results in large positive forecast errors and the latter scenario implies large negative forecast errors. Extra timing skill implies a positive relation between the changes in weights and the forecast errors.

The following model provides a test for extra timing skill:

$$
\begin{aligned}
\Delta w_{i t}= & \theta_{i 1}+\theta_{i 2} I\left(r_{m, t+1}^{+} \& E_{t}^{-}\left[r_{m, t+1}\right]\right)+\theta_{i 3} I\left(r_{m, t+1}^{-} \& E_{t}^{+}\left[r_{m, t+1}\right]\right) \\
& +\theta_{i 4} I\left(r_{m, t+1}^{+} \& E_{t}^{+}\left[r_{m, t+1}\right]\right)+\theta_{i 5} I\left(r_{m, t+1}^{-} \& E_{t}^{-}\left[r_{m, t+1}\right]\right)+\epsilon_{i, t+1} .
\end{aligned}
$$

If the newsletters are correctly interpreting the common information about the conditional means (holding conditional variances constant), both $\theta_{4}>0$ and $\theta_{5}<$ 0 . Positive values of $\theta_{2}$ and negative values of $\theta_{3}$ indicate extra timing ability. Likewise, coefficients $\theta_{2}>0$ and $\theta_{3}<0$ from the regression with the demeaned value of $w_{i t}$ as dependent variable indicate that the weights are above or below average at times which correctly defy the common market expectation.

The results of estimating a pooled version of (5) are presented in table 2 and individual portfolio estimations are summarized in figure 3 . The signs of the coefficients which measure the correct interpretation of common information are correct in panel A. However, only $50.3 \%$ of investment letters decrease weights when both the expected and actual market return was negative and only $48.5 \%$ increase weights when both expected and actual returns are positive. Similar results are found in the demeaned weight levels in panel B. Portfolios are $8.55 \%$ below the average equity weight when both expected and actual returns are negative. The portfolios have $4.16 \%$ above average market weights when both expected and actual returns are positive. These coefficients are significant at the $5 \%$ level.

There is no evidence that the investment portfolios exhibit any extra market timing. Portfolio weights increase in $62.6 \%$ of the cases when the expected market returns are positive and the realized returns are negative. Portfolio weights decrease in $60.0 \%$ of the cases when the expected market return is negative and the realized return is positive. In the demeaned market weights in panel $\mathrm{B}$, the absence of extra market timing is evident at the $10 \%$ level of significance.

Of course, a newsletter may decrease the weight in the market even if the excess market return is expected to be positive because the market variance is 
forecasted to increase. While we focus on the conditional means, we also report in the last rows of Table 2 a version of (5) which allows for both changing conditional means and variances. The number of indicator variables is increased to eight (4 for increasing expected volatility and 4 four decreasing expected volatility). Four of the indicators have unambiguous signs. For example, if the market goes up and volatility is forecasted to decrease, then the equity weight should increase. The unambiguous coefficients are presented in bold typeface.

Allowing for time-varying volatility does not improve the the performance newsletter recommendations. In situations when the market is expected to go up and it does, only $48.5 \%$ of the newsletters increase equity weights $\left(\theta_{4}\right)$. If we subset the dates when volatility was expected to decrease, there are fewer newsletters recommending increased weights, $47.0 \%$. A similar picture emerges from the case when both the expected and realized market returns are negative. Using all the data, $50.3 \%$ of the letters recommended increased investment weights $\left(\theta_{5}\right)$. Subsetting the situations when volatility was expected to increase, $60.9 \%$ recommended higher equity weights. Neither of these proportions are impressive; ideally, they should both be near $0.0 \%$. This suggests that subsetting by volatility predictions causes a deterioration in the newsletter performance.

Subsetting the data leads to slightly better performance in the extra market timing measures. When the market goes up but the expected return was negative, only $40 \%$ of the newsletters increased investment weights $\left(\theta_{2}\right)$. However, if we further subset to isolate situations where volatility was expected to decrease, $58.3 \%$ of the newsletters increased investment weights. Similarly, when the expected return was positive and the realized return negative $\left(\theta_{3}\right), 62.6 \%$ of the letters were increasing market weights. However, if we examine the dates when expected volatility was increasing, a reduced percentage, $52.6 \%$, recommended increasing weights. Overall, the evidence suggests that allowing for time-varying variances in addition to conditional means, has little impact on the newsletters' timing abilities. 


\subsection{Does good performance indicate good future performance?}

There are a number of studies which suggest that mutual fund performance persists. ${ }^{13}$ One common problem with these studies, as pointed out by Lehmann and Modest (1987), is that the evidence of persistence could be sensitive to the method used to compute risk-adjusted returns. The risk adjustment problem is also highlighted by Harvey (1992) who reports that aggressive growth funds show twice the persistence of balanced and growth mutual funds. This relation between risk and persistence suggests that an incorrect risk adjustment may induce some of the persistence.

While it is impossible to bypass the risk adjustment issue, at least we do not need to worry about the estimation of the conditional betas. We subset our portfolio returns into three four-year periods. The cross-section of the abnormal returns (measure 2) in the second period is regressed on the abnormal returns in the first period. The regression is re-estimated for the second and third periods. We also report a pooled regression. These results are presented in Table 3.

The persistence of performance is much more evident in investment letter returns than in mutual fund returns. The persistence coefficients in the first and second periods are 0.83 and 0.62 , respectively. In addition, there is an important similarity between investment letter and mutual fund performance persistence: the results are being driven by poor performance. For example, in Harvey's (1992) analysis of aggressive growth funds in the 1982-1988 period, only 15 of 67 funds had positive abnormal returns in any of the two periods and none of the funds had positive abnormal returns in both three year periods. Similarly, Figure 4 shows that only 3 of 46 had positive abnormal performance in consecutive periods. That is, the evidence of persistence is being driven by negative performance.

Brown, Goetzmann, Ibbotson and Ross (1992) argue that some persistence

${ }^{13}$ See Elton and Gruber (1989), Grinblatt and Titman (1988), Lehmann and Modest (1987), Hendricks, Patel and Zeckhauser (1991) and Goetzmann and Ibbotson (1994). Brown, Goetzmann, Ibbotson and Ross (1992) argue that the findings of persistence could be sensitive to the survivorship bias problem in the data. 
is induced by the survivorship bias problem. It is possible that our requiring newsletters to exist in two consecutive four-year periods in the previous regression analysis could induce persistence. In response to this, we present a nonparametric analysis of persistence. Table 3 shows that after one year of outpacing the S\&P portfolio (measure 2), there is only a $37.3 \%$ chance that the newsletter portfolio will outperform this portfolio in the following year. If the newsletter portfolio produced two consecutive years of extra returns, the probability that it will succeed in the next year is $47.6 \%$. For three and four years, the probabilities are $45.2 \%$ and $54.5 \%$, respectively. The evidence of persistence is far less impressive using the nonparametric approach which supports the Brown et al. argument that survivorship could induce spurious persistence.

Table 3 also investigates the persistence of negative abnormal returns. Given one year of negative abnormal returns, there is a $67.6 \%$ chance that the next year will be negative. With two negative abnormal return years, there is a $66.5 \%$ chance that the next year will be also be negative. The probabilities increase to $71.1 \%$ and $76.2 \%$ over the next two years. ${ }^{14}$ In addition, the frequencies of the negative abnormal return runs are much greater than the positive abnormal returns runs. For example, 168 newsletter year observations meet the criteria of three consecutive negative abnormal return years. This is sharply higher than the 30 newsletter year observations associated with three consecutive positive abnormal return years.

\section{The information in newsletters' forecasts}

\subsection{Implied expected returns}

Our sample includes recommendations of asset allocation weights - not market forecasts. However, it is possible to impute the newsletters' forecasts of the market return. If we assume that the newsletter subscribers have negative exponential

14 Christopherson, Ferson and Glassman (1994) find evidence of performance persistence is concentrated on managers with negative conditional performance. 
utility and returns are normally distributed, expected returns on the individual assets in portfolio $i, E\left[\boldsymbol{r}_{i}\right]$, can be expressed as:

$$
E\left[\boldsymbol{r}_{i}\right]=\lambda_{i} \boldsymbol{\Sigma} \boldsymbol{w}_{i}
$$

where $\boldsymbol{\Sigma}$ is the variance-covariance matrix of asset returns, $\boldsymbol{w}_{i}$ are the weights in the portfolio and $\lambda_{i}$ is the coefficient of relative risk aversion.

In our problem, there is only one risky asset, the market portfolio. Given an estimate of the variance of the market, the variance of the conditionally expected returns, the unconditional mean return, and the known weights, we can infer the risk aversion of each newsletter. ${ }^{15}$ To make the average returns and variances meaningful, we require at least four years of monthly data. This ensures that the returns span the average length of one business cycle. We assume that all investors agree on the unconditional means and variances.

Importantly, this technique allows for different risk aversions across newsletters. An examination of the average recommended weights reveals that newsletters appeal to different clienteles of investors with different risk aversion. In our sample, the risk aversion coefficients range from 1.96 for the Wall Street Generalist which, as noted before, had a portfolio volatility $60.8 \%$ per annum to 16.50 for the Professional Timing Service-(no shorting) which had a volatility of only $7.1 \%$ (with an average of $60 \%$ of funds in cash). The mean (median) risk aversion is 7.19 (6.93); the frequency distribution is presented in Figure 5. These implied risk aversion coefficients are similar to the average ratio of expected excess return to variance over the 13 year sample, 6.29 , and to the average risk aversion estimates presented in Campbell (1987) and Harvey (1989).

The risk aversion is calculated using the unconditional variance and expected returns. To infer the time-series of conditionally expected returns, we calculate:

$$
E_{t}\left[r_{i, t+1}\right]=\lambda_{i} E_{t}\left[\sigma_{t+1}^{2}\right] w_{i t}
$$

15 This intuition follows French and Poterba (1991) who use data on aggregate investment weights in the U.S. and Japan to infer the expected returns in the two markets. They present results which assume that $\lambda$ is equal to three. We solve for $\lambda_{i}$ in $E\left[r_{i}\right]=\lambda_{i}\left(\operatorname{Var}\left[r_{i}\right]-\operatorname{Var}\left[E\left\{r_{i} \mid Z\right\}\right]\right) w_{i}$. 
The constant risk aversion is multiplied by both the time-varying expected volatility proxy and the time-varying weights. We assume that all investors have the same forecast of volatility. ${ }^{16}$

We use the generalized autoregressive conditional heteroskedasticity (GARCH) model proposed by Engle (1982) and Bollerslev (1986) to obtain the volatility forecasts. The specific implementation follows French, Schwert and Stambaugh (1987) and Schwert and Seguin (1990) in that monthly ex post variances are calculated from daily S\&P 500 returns from 1959-1992. Also similar to these papers, we estimate a $\operatorname{GARCH}(1,1)$ model. However, there are two differences. First, our specification of the mean follows the statistical model which uses five instrumental variables. Second, we initially fit the model with data through 1980:05 and obtain an out-of-sample volatility forecast for 1980:06. At every month, the estimation is repeated until we have a complete series of out-of-sample volatilities.

Table 4 analyzes the imputed newsletter predictions. We present both the mean and median newsletter forecast as well as the forecasts from the statistical model. Strong evidence in favor of looking at the mean forecast is provided by Clemen (1989) who concludes that a simple average is the best method of combining forecasts across a wide range of forecasting environments. In the spirit of Clemen and Winkler (1986), we use an alternative approach which averages forecasts by weighting each recommendation inversely by the square the newsletter s previous forecast error.

Some summary statistics on the predictions are presented in Table 4. We examine the full sample with and without the October 1987 observation as well as the shorter, post-1986 sample, which is out-of-sample for the statistical model.

16 Another possibility, suggested by Wayne Ferson, is to let the newsletters' weights enter the conditional variance function in the GARCH model. This would produce newsletter specific variance estimates. Of course, the cross-sectional dispersion of the newsletters' forecasts could be affected by the assumption about a common expected volatility. However, in addition to the computational burden of estimating a GARCH model for each newsletter at each point in time, many of models would be fit over very small samples making it unlikely that the estimation would converge. 
In terms of mean squared error and mean absolute errors, all four forecasts are similar. The mean and median forecasts tend to do slightly better than the performance weighted newsletter forecasts. The newsletters present better correct direction counts (over the full sample 62.7\%) than the statistical model. However, all of the combined newsletter forecasts are positive. That is, there was never a month where there was an average short market position. Hence, the correct direction count is not that revealing.

The magnitude of the forecast as well as the direction provides a better measure of performance. We regress the market return on the forecasted market returns from the different models. In the full sample (omitting the crash observation), the statistical model presents a $3 \%$ adjusted $R^{2}$ whereas the newsletter models all have zero $R^{2}$ s. Similar results are found in the post-1986 sample. The out-of-sample adjusted $R^{2}$ is $1 \%$ for the statistical model and negative $1 \%$ for the newsletter models.

\subsection{Volume, volatility and forecast dispersion}

There is considerable interest in the relations between volume, volatility of price changes and agents' forecasts. Harris and Raviv (1993) develop a model which has implications about changes in the mean forecasted returns and volume. Shalen (1993) presents a model where changes in the agents' forecast dispersion induce trading. Her model predicts that increased dispersion will cause increased trading volume and increased volatility. Our data provide an ideal setting to test these predictions.

Ziebart (1990) examines the relation between a security's market-adjusted volume, the change in dispersion of analyst's forecasts, and the absolute value of the revision in the mean earnings forecast. He finds the dispersion and change in the mean variables are significantly related to volume. This supports the Harris and Raviv (1993) prediction.

Frankel and Froot (1990) present empirical results which suggest that volume. 
volatility and the standard deviation of forecasts across respondents to the weekly Money Market Services international survey of currency exchange rates are all positively correlated. They show that dispersion Granger-causes volume as well as volatility. These results are consistent with the Shalen (1993) model. ${ }^{17}$

Few have studied the equity market as a whole. ${ }^{18}$ The first two panels summarize the contemporaneous correlations between dispersion, volatility, trading volume, and the change in the aggregated newsletter forecasted return. Two measures of volatility are examined. The first is the ex post volatility from the daily S\&P 500 returns converted to monthly. The second volatility is the implied volatility on the Chicago Board of Options Exchange's Market Volatility Index. ${ }^{19}$

The panels show the correlations of the levels as well as first differences in the levels. All of the variables are positively correlated. The correlations using the historical volatility and the implied volatility are remarkably similar though the implied volatility is only available over a shorter sample.

In panel B, we report a test of one of the Harris and Raviv (1993) predictions. The Harris and Raviv model does not imply a causal relation between volume and forecast change. Instead, the variables are positively correlated because they are both driven by a third exogenous factor, namely a signal. In support of their model, the contemporaneous correlation between the change in the absolute value of the market forecast and volume is $38 \%$ and significant at the $1 \%$ level.

17 Holthausen and Verrecchia (1990) also present a model which links dispersion to volatility. Their model implies a negative relation, the opposite of Shalen's (1993) prediction. O'Brien (1988) examines whether agents produce more accurate earnings forecasts than mean or median forecasts. Tauchen and Pitts (1983) and Gallant, Tauchen and Rossi (1992a,b) examine volume and volatility relation for the market as a whole.

18 The first published study is Cowles (1933). There are a number of studies which analyze the semi-annual predictions of academic and business economists published by Joseph Livingston in the Philadelphia Inquirer. See Lakonishok (1980), Brown and Maital (1981), Pearce (1984) and Dokko and Edelstein (1989).

19 See Harvey and Whaley (1992) for the methodology of constructing the implied volatilities. See Whaley (1993) for a description of how a basket of volatilities is combined into a single index. The time series properties of the index and data are provided by Fleming, Ostdiek and Whaley (1993). 
The third panel of Table 5 analyzes whether changes in dispersion Grangercause changes in volatility and NYSE volume (adjusted by the total number of shares outstanding). The results show that dispersion Granger-causes both volume and volatility which is consistent with predictions of Shalen (1993). These findings are robust to the choice of proxy for volatility.

The final panel of table 5 shows the result of a one standard deviation shock in the variables of interest. A shock in dispersion affects future levels of dispersion. A one standard deviation shock increases future dispersion by $33 \%$ after three months. In addition, a one standard deviation jump in dispersion causes trading volume to increase by $15 \%$ in the first month. Most importantly, there is an economically significant relation between dispersion and market volatility. A one standard deviation shock in dispersion implies a sharp jump market volatility in the first month. There is a reversal in the second month. The three month impact of the innovation is an $11 \%$ increase in the level of volatility.

\section{Conclusions}

We analyze over 15,000 asset allocation recommendations from investment newsletters from 1980-1992. The investment letters suggest a mixture of equity and cash. In contrast to mutual fund studies, we directly observe the asset weights. Since the conditional market beta is unity and the conditional beta of cash is zero, we bypass the risk estimation.

We nonparametrically assess the performance of the investment letters by forming portfolios which incorporate their recommendations and comparing performance against a fixed investment weight cash/S\&P 500 portfolio which has the same unconditional variance. We find that over $75 \%$ of the newsletters produce negative abnormal returns. Some recommendations are remarkably poor. For example, the (once) high profile Granville Market Letter-Traders produced an average annual loss of $5.4 \%$ over the past 13 years. This compares to a $15.9 \%$ average annual gain on the Standard and Poor's 500 price index. 
Our tests focus on the ability of these analysts to call the direction of the market - or market timing. We find little evidence that equity weights increase before future positive market returns and decrease before negative market returns. We argue that timing should be evaluated relative to the common-knowledge degree of predictability in the economy. We propose a statistical model which serves as a benchmark for the common level of predictability. We measure 'extra' market timing as instances when equity weights increase (decrease) when the common expected returns are negative (positive) and future realized returns are positive (negative). We find no evidence that the investment letters as a group have any knowledge over and above the common level of predictability.

We also examine whether performance is persistent. When we run crosssectional regressions of four-year performance on the previous four-year performance, we can account for nearly $50 \%$ of the cross-sectional variance. This evidence is much stronger than complementary evidence presented in mutual fund studies. However, following Brown, Goetzmann, Ibbotson, and Ross (1992), some persistence could be induced by a survivorship bias when the cross-sections are sampled. Consistent with this observation and when the measurement horizon is shortened, there is little evidence of persistence of good performance. If the investment letter produced two consecutive years of positive abnormal performance, there is less than $50 \%$ chance that the positive performance will persist in the next year. However, there is formidable evidence of persistence in poor performance. If the investment letter produced two consecutive years of negative abnormal performance, there is almost a $70 \%$ chance that the next year's performance will also be poor.

We infer each investment letter's assessment of the expected market return from their recommendations. We construct various consensus metrics and find that the consensus expectation contains little information about the future market return. These results are consistent with our analysis of the individual newsletters. Treated individually or aggregated, the newsletters offer little information about the direction or the magnitude of market returns.

While there is little value in the aggregate predicted market return, impor- 
tant information exists in the disagreement among the forecasters. Theoretical models, such as the one proposed in Shalen (1993), show that increased disagreement should predict both increased trading volume and increased volatility. The standard deviation of the newsletters' forecasts provides a natural measure of disagreement and we are able to provide the first tests of these predictions for broad equity market return. Our evidence suggests that dispersion Granger-causes both volatility and trading volume. In addition, our time-series analysis of the impact of unanticipated increases in dispersion suggests that the measure has an econonically meaningful influence on both volume and volatility.

The bottom line is that very few newsletters can 'beat' the S\&P 500 according to the measures that we study. In addition, few can 'beat' the market forecasts derived from a statistical representation of publicly available information. There is no evidence that the letters can time the market (forecast the direction). Consistent with mutual fund studies, 'winners' rarely win again and 'losers' often lose again. Finally, while there is little value in the magnitude and the direction of aggregate forecast of the market return, there is important information in the cross-sectional uncertainty or dispersion. Our results show that dispersion anticipates both volume and volatility. 


\section{References}

Bansal, Ravi and Campbell R. Harvey, 1994, Performance in the presence of dynamic trading strategies, Unpublished working paper, Duke University, Durham, NC.

Bjerring, James H., Josef Lakonishok and Theo Vermaelen, 1983, Stock prices and financial analysts's recommendations, Journal of Finance 38, 187-204.

Black, Fischer, 1993, Estimating expected return, Financial Analysts Journal, September/October, 36-38.

Bollerslev, Tim, 1986, Generalized autoregressive conditional heteroskedasticity, Journal of Econometrics 307-327.

Brown, Bryan W. and Shlomo Maital, What do economists know? An empirical test of experts: expectations, Econometrica 49, 491-504.

Brown, Stephen J., William Goetzmann, Roger G. Ibbotson and Stephen A. Ross, 1992, Survivorship bias in performance studies, Review of Financial Studies 5, 553-580.

Campbell, J. Y., 1987, Stock returns and the term structure, Journal of Financial Economics $18,373-400$.

Chen, Zhiwu and Peter J. Knez, 1993, Mutual fund performance: A nonparametric empirical investigation, Working paper, University of Wisconsin, Madison, WI.

Christopherson, Jon A., Wayne E. Ferson and Debra Glassman, 1994, Conditioning manager alphas on economic information: Another look at the persistence in performance, Unpublished working paper, University of Washington, Seattle, WA.

Clemen, Robert, 1989, Combining forecasts: A review and annotated bibliography, International Journal of Forecasting 5, 559-583.

Clemen, Robert and Robert Winkler, 1986, Combining economic forecasts, Journal of Business and Economic Statistics 4, 369-391.

Cowles, Alfred III, 1933, Can stock market forecasters forecast? Econometrica 1, 309-324.

Dimson, Elroy and Paul Marsh, 1984, An analysis of brokers' and analysts' unpublished forecasts of UK stock returns, Journal of Finance 39, 1257-1292.

Dokko, Yoon and Robert H. Edelstein, 1989, How well do economists forecast stock market prices? A study of the Livingston surveys, American Economic Review 79, 865-871.

Elton, Edwin J., Martin J. Gruber and Seth Grossman, 1986, Discrete expectational data and portfolio performance, Journal of Finance 41, 699-713.

Elton, Edwin J. and Martin J. Gruber, 1989, Modern Portfolio Theory and Investment Analysis Wiley, New York.

Engle, Robert F., 1982, Autoregressive conditional heteroskedasticity with estimates of U.K. inflation, Econometrica 50, 987-1008.

Fama, Eugene F. and Kenneth R. French, 1988, Dividend yields and expected stock returns, Journal of Financial Economics 22, 3-26.

Fama, Eugene F. and Kenneth R. French, 1989, Business conditions and expected returns on stocks and bonds, Journal of Financial Economics 25, 23-50.

Ferson, Wayne E. and Campbell R. Harvey, 1991, The variation of economic risk premiums, Journal of Political Economy 99, 285-315. 
Ferson, Wayne E. and Rudi Schadt, 1994, Measuring fund strategy and performance in changing economic conditions, Unpublished working paper, University of Washington, Seattle, WA.

Foster, F. Douglas and Tom Smith, 1993, Assessing goodness-of-fit of asset pricing models: The distribution of the maximal R-square. Working paper, Duke University, Durham, NC.

Frankel, Jeffery and Kenneth Froot, 1990, Chartists, fundamentalists, and trading in the foreign exchange market, American Economic Review 80, 181-185.

French, Kenneth R. and James M. Poterba, 1990, Japanese and U.S. cross-border common stock investments, Journal of the Japanese and International Economies 4, 476-493.

French, Kenneth R., G. William Schwert, and Robert F. Stambaugh, 1987, Expected stock returns and volatility, Journal of Financial Economics 19, 3-30.

Gallant, A. Ronald, George Tauchen and Peter E. Rossi, 1992a, Nonlinear dynamic structures, Econometrica 61, 871-907.

Gallant, A. Ronald, George Tauchen and Peter E. Rossi, 1992b, Stock prices and volume, Review of Financial Studies 5, 199-242.

Goetzmann, William and Roger Ibbotson, 1994, Do winners repeat? Patterns in mutual fund behavior, Journal of Portfolio Management.

Grinblatt, Mark and Sheridan Titman, 1989, Mutual fund performance: An analysis of quarterly portfolio holdings, Journal of Business 62, 393-416.

Grinblatt, Mark and Sheridan Titman, 1990, Portfolio performance evaluation: Old issues and new insights, Review of Financial Studies 2, 393-421.

Groth, John C., Wilbur G. Lewellen, Gary G, Schlarbaum and Ronald C. Lease, 1979, An analysis of brokerage house securities recommendations, Financial Analysts Journal January/February, 32-40.

Harris, Milton and Arthur Raviv, 1993, Differences of opinion make a horse race, Review of Financial Studies 6, 473-506.

Harvey, Campbell R., 1989, Time-varying conditional covariances in tests of asset pricing model, Journal of Financial Economics 24, 289-317.

Harvey, Campbell R., 1992, Discussion of 'Survivorship bias in performance studies,' Unpublished discussion, Western Finance Association meetings.

Henriksson, Roy D. and Robert C. Merton, 1981, On market timing and investment performance. II. Statistical procedures for evaluating skills, Journal of Business 54, 513-553.

Hendricks, D., J. Patel and R. Zechhauser, 1993, Hot hands in mutual funds: The persistence of performance, 1974-1988, Journal of Finance.

Holthausen, Robert and R. Verrecchia, 1990, The effect of informedness and consensus in price and volume behavior, Accounting Review 65, 191-208.

Jensen, Michael, 1968, The performance of the mutual funds in the period 1954-1964, Journal of Finance 23, 384-416.

Lakonishok, Josef, 1980, Stock market return expectations: Some general properties, Journal of Finance 35, 921-30.

Lehmann, Bruce and David Modest, 1987, Mutual fund performance evaluation: A comparison of benchmarks and benchmark comparisons, Journal of Finance 21, 233-265. 
Lo, Andrew and Craig A. MacKinlay, 1990, Data-snooping biases in tests of financial asset pricing models, Review of Financial Studies 3, 431-467.

Merton, Robert C., 1981, On market timing and investment performance. I. An equilibrium theory of value for market forecasts, Journal of Business 54, 363-406.

O'Brien, Patricia, 1988, Analysts forecasts as earnings expectations, Journal of Accounting and Economics 10, 53-83.

Pearce, Douglas K, 1984, An empirical analysis of expected stock returns, Journal of Money Credit and Banking 16, 317-327.

Schwert, G. William and Paul J. Seguin, 1990, Heteroskedasticity in stock returns, Journal of Finance 45, 1129-1155.

Shalen, C., 1993, Volume, volatility and the dispersion of beliefs, Review of Financial Studies 6, 405-434.

Tauchen, George and Mark Pitts, 1983, The price variability-volume relationship on speculative markets, Econometrica 51, 485-505.

Treynor, Jack and F. Muzay, 1966, Can mutual funds outguess the marker? Harvard Business Review 44, 131-136.

Whaley, Robert E., 1993, Derivatives on market volatility: Hedging tools long overdue. Journal of Derivatives, 71-84.

Womack, Kent L., 1994, Do brokerage analysts' recommendations have investment value, Unpublished working paper, Cornell University, Ithaca, NY.

Ziebart, D., 1990, The association between consensus beliefs and trading activity surrounding earnings announcements, Accounting Review 65, 477-488. 
</ref_section> 
Table 1

Investment newsletter summary statistics, June 1980 to December 1992

\section{Invesment newslenter}

STATISTICAL MODEL

EQUALLY WEIGHTED NEWSLETTER EQUALLY WEIGHTED NEWSLETTER ( $>4$ yeats)

DINES LETTER (SHORTING)

DLNES LETTER (NO SHORTING)

DOW THEORY LETTERS

GRANVILLE MARKET LETTER (TRADERS)

GRANVILLE MARKET LETTER (INVESTORS)

MARKET LOGIC

PROFESSIONAL TAPE READER (MUTLAL FLND)

PROF. TMMING SERVICE (SHORTING)

PROF. TIMLNG SERVICE (NO SHORTING)

TELEPHONE SWITCH NEWSLETTER

VALUE LNE INVESTMENT SURVEY

ZWEIG FORECAST-MODEL PORTFOLIO

DINES LETTER-SHORT TERM TRADIYG

PROFESSIONAL TAPE READER-MODEL

BOB NUROCK'S ADVISORY (TMI:NO SHORT)

BOB NUROCK'S ADVISORY (TMI:SHORTING)

OUTLOOK--MARKET ALLOCATION

CHARTIST-ACTUAL CASH AC:OUNT

ELLIOTT WAVE THEORIST (INVESTORS)

GROWTH STOCK OUTLOOK

CABOT MARKET LETTER--MODEL PORTFOLIO

THE BIG PICTURE (NO SHORTLNG)

THE BIG PICTURE--SGA-SHORTING ALLOWED

SYSTEMS \& FORECASTS.- TLME TRE.VD'

THE BIG PICTURE--TRADING PORTFOLIO

PETER DAG INVESTMENT LETTER

CHARTIST --TRADERS

SYSTEMS \& FORECASTS ISHORTING,

CALIFORVLA TECHNOLOGY STOCK LETTER

PRINCETON PORTFOLIOS -FORTFOLIO :2

FUND EXCHANGE

BOB NUROCK'S ADVISORY --MODEL

MARGO'S MARKET MONITOR

MARKET MANLA-TMING ONLY

INVESTECH MARKET ANALYST

SPECLLATOR TRADERS PORTFOLIO

INVESTECH MUTUAL FUND ADVISOR

MUTUAL FUND STRATEGIST (INVESTORS)

MUTUAL FUND STRATEGIST (INTERMEDLATE)

PROF. TLMING SERVICE (SHORT ON SELL)

STOCKMARKET CYCLES (MUTLAL FUND)

ZWEIG FORECAST (NO SHORT)

WELLINGTON'S WORRY-FREE INVESTING

PSR STOCKWATCH-MODEL

HOLT INVESTMENT ADYISORY

NAME LNKNOWN

STOCKMARKET CYCLES (MODEL)

MARKETARIAN-MUTUAL FUND IVVVESTOR

INYESTECH MUTUAL FUND ADVISOR

ZWEIG-ST TREND INDICATOR (SHORTING!

\begin{tabular}{|c|c|c|c|c|c|c|}
\hline $\begin{array}{l}\text { Forecase } \\
\text { penge. }\end{array}$ & $\begin{array}{l}\text { Newslener } \\
\text { return } \\
\text { Gafter } ! \text { costs }\end{array}$ & $\begin{array}{c}\text { S\&P } 500 \\
\text { rewa" } \\
\text { afier L costs) }\end{array}$ & $\begin{array}{l}\text { Newsletuer } \\
\text { volatility }\end{array}$ & $\begin{array}{l}\text { S\&P } 500 \\
\text { yolatititx }\end{array}$ & $\begin{array}{l}\text { Measure } 1 \\
\text { abrormal } \\
\text { rerum }\end{array}$ & $\begin{array}{l}\text { Measure } 2 \\
\text { abnormal } \\
\text { Eenume }\end{array}$ \\
\hline$: 06-92: 12$ & $0.171(0.154)$ & $0.159(0.158)$ & 0.124 & 0.159 & $0.011 \cdots$ & $0.014^{\cdots}$ \\
\hline $06-92: 12$ & $0.113(0.109)$ & $0.159(0.158)$ & 0.084 & 0.159 & $-0.015^{\circ}$ & $-0.042^{\circ}$ \\
\hline$: 06-92: 12$ & $0.112(0.107)$ & $0.159(0.158)$ & 0.081 & 0.159 & $-0.016^{\circ}$ & $0.042^{\circ}$ \\
\hline$: 06-92: 12$ & $-0.004(-0.004)$ & $0.163(0.162)$ & 0.170 & 0.163 & $-0.170^{\circ}$ & $-0.162^{\circ}$ \\
\hline $80: 06-92: 12$ & $0.124(0.107)$ & $0.163(0.162)$ & 0.126 & 0.163 & $-0.039^{\circ}$ & $0.050^{\circ}$ \\
\hline $80: 06-92: 10$ & $0.146(0.137)$ & $0.197(0.196)$ & 0.095 & 0.139 & $-0.026^{\circ}$ & $0.039^{\circ}$ \\
\hline $80: 06-92: 12$ & $-0.049(-0.054)$ & $0.156(0.155)$ & 0.155 & 0.163 & $-0.207^{\circ}$ & $-0.215^{\circ}$ \\
\hline $80: 06-92: 06$ & $0.134(0.125)$ & $0.159(0.158)$ & 0.119 & 0.166 & $-0.015^{\circ}$ & $-0.021^{\circ}$ \\
\hline $30: 06-92: 12$ & $0.144(0.143)$ & $0.139(0.138)$ & 0.139 & 0.167 & $0.012^{\circ}$ & $0.014^{\circ}$ \\
\hline $30: 06-92: 02$ & $0.130(0.114)$ & $0.165(0.164)$ & 0.072 & 0.164 & -0.008 & -0.017 \\
\hline $80: 06-92: 12$ & $-0.018(-0.022)$ & $0.200 \times 0.199)$ & 0.148 & 0.142 & $-0.227^{\circ}$ & $-0.216^{\circ}$ \\
\hline $80: 06-92: 12$ & $0.139(0.121)$ & $0.200 \times(0.199)$ & 0.071 & 0.142 & $-0.021^{\circ}$ & $-0.043^{\circ}$ \\
\hline $80: 06-92: 12$ & $0.113(0.102)$ & $0.155(0.154)$ & 0.135 & 0.166 & $-0.041^{\circ}$ & $-0.050^{\circ}$ \\
\hline$: 12$ & 0.144 & 0.157 & 0.103 & 0.141 & 0.003 & 0.004 \\
\hline $80: 06-92: 12$ & $0.130(0.120)$ & $0.159(0.158)$ & 0.078 & 0.159 & -0.001 & -0.003 \\
\hline $80: 06-92: 12$ & $0.110(0.096)$ & $0.159(0.158)$ & 0.096 & 0.159 & $-0.034^{\circ}$ & $-0.057^{\circ}$ \\
\hline $80: 06$ & 0.109 & $0.158(0.157)$ & 0.069 & 0.159 & $-0.017^{\circ}$ & $-0.040^{\circ}$ \\
\hline $80: 06-90: 08$ & 0.231 ( & $0.149(0.148)$ & 0.117 & 0.148 & $0.085^{\circ}$ & $0.110^{\circ}$ \\
\hline $80: 06-90: 08$ & 0.199 & $0.149(0.147)$ & 0.144 & 0.148 & $0.051^{\circ}$ & $0.055^{\circ}$ \\
\hline $80: 06-92: 12$ & 0.144 & $0.189(0.187)$ & 0.095 & 0.155 & $-0.008^{\circ}$ & $-0.012^{\circ}$ \\
\hline 80:07. & $0.121(4$ & $0.152(0.151)$ & 0.098 & 0.157 & $0.012^{\circ}$ & $-0.020^{\circ}$ \\
\hline $80: 07-92: 10$ & 0.119 & $0.157(0.156)$ & 0.143 & 0.167 & $-0.041^{\circ}$ & $-0.046^{\circ}$ \\
\hline $80: 07-92: 09$ & $0.108(c$ & $0.146(0.145)$ & 0.067 & 0.158 & -0.005 & $-0.014^{*}$ \\
\hline $80: 12$ & 0.129 & 147) & 0.131 & 0.161 & $2^{*}$ & $-0.015^{\circ}$ \\
\hline $81: 12-92: 12$ & 0.107 & 0.155 & 0.091 & 0.160 & $6^{*}$ & $81^{\circ}$ \\
\hline $81: 12-92: 12$ & $-0.033(-0.034)$ & $0.155(0.154)$ & 0.165 & 0.160 & -0 . & $-0.184^{\circ}$ \\
\hline $82: 12-92: 10$ & $0.119(0.100)$ & $0.153(0.152)$ & 0.143 & 0.158 & -0 . & $-0.050^{\circ}$ \\
\hline $82: 12-92: 12$ & $0.116(0.110)$ & $0.162(0.161)$ & 0.080 & 0.157 & -0 . & $10^{\circ}$ \\
\hline $82: 1$ & 0.140 & $0.162(0.161)$ & 0.091 & 0.158 & $.0^{\circ}$ & $0.018^{\circ}$ \\
\hline 83.1 & 0.16 & $0.176(0.175)$ & $0.15 s$ & 0.163 & -0 . & -0.004 \\
\hline $82: 12$ & 0.05 & $0.153(0.152)$ & 0.163 & 0.158 & $-0.103^{\circ}$ & $-0.099^{\circ}$ \\
\hline $83: 01-92: 12$ & 0.13 & 0.162 & 0.092 & 0.157 & 0.004 & 0.007 \\
\hline $83: 01-92: 12$ & 0.114 & $0.168(0.167)$ & 0.070 & 0.157 & $-0.013^{\circ}$ & $-0.030^{\circ}$ \\
\hline $3: 12-92: 12$ & 0.160 & $0.194(0.193)$ & 1 & 42 & & $4 \cdots$ \\
\hline $3: 12-92: 12$ & 0.116 & $0.141(0.140)$ & 0.1 & 67 & 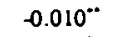 & $5^{\circ}$ \\
\hline 4:01 & 0.18 & $0.202(0.201)$ & 0.128 & 41 & $07^{*}$ & $06^{\circ}$ \\
\hline $84: 01$ & 0.1 & $0.119(0.118)$ & 0.213 & 0.167 & 10 & -0.008 \\
\hline $84: 0$ & 0.1 & $0.167(0.166)$ & 0.064 & 0.168 & -0.003 & -0.008 \\
\hline $84: 01 \cdot 89: 09$ & 0.1321 & $4(0.183)$ & 0.121 & 0.174 & $-0.032^{\circ}$ & $-0.047^{\circ}$ \\
\hline $84: 12-92 ; 07$ & 0.1221 & $0.154(0.152)$ & 0.089 & 182 & 0.001 & 0.002 \\
\hline $84: 12-89: 01$ & $0.103(0.089)$ & $0.223(0.220)$ & 0.167 & 0.189 & $-0.116^{\circ}$ & $-0.130^{\circ}$ \\
\hline $84: 12-92: 09$ & $0.076(0.049)$ & $0.168(0.167)$ & 0.1 & 0.170 & $-0.092^{\circ}$ & $-0.129^{\circ}$ \\
\hline $84: 12-88: 12$ & $0.200 \times(0.176)$ & $0.316(0.310)$ & 0.089 & 0.116 & $-0.078^{\circ}$ & $-0.100^{\circ}$ \\
\hline$: 08$ & 0.07 & $0.152(0.151)$ & & 9 & & -0.108 \\
\hline $84: 1$ & & 0.1 & 0.089 & 67 & $1^{*}$ & $-0.133^{\circ}$ \\
\hline $84: 12-86: 12$ & 0.16 & $0.219(0.214)$ & 0.1 & 0.149 & $-0.041^{\circ}$ & $-0.041^{\circ}$ \\
\hline $84: 12-86: 12$ & $0.202(0.198)$ & $0.219(0.214)$ & 0.1 & 0.149 & $-0.00 t$ & 0.003 \\
\hline $84: 12-86: 08$ & $0.026(-0.030)$ & $0.327(0.320)$ & 0.045 & 0.132 & $-0.185^{\circ}$ & $-0.523^{\circ}$ \\
\hline $84: 12-85: 06$ & $0.217(0.201)$ & $0.382(0.362)$ & 0.102 & 0.115 & $-0.143^{\circ}$ & $-0.146^{\circ}$ \\
\hline $84: 12 \cdot 92: 12$ & $0.052(0.037)$ & $0.150(0.149)$ & 0.107 & 0.173 & $-0.082^{\circ}$ & $-0.133^{\circ}$ \\
\hline $84: 12.91: 01$ & $0.043(0.025)$ & $0.135(0.133)$ & 0.144 & 0.181 & $-0.099^{\circ}$ & $-0.123^{\circ}$ \\
\hline $84: 12-92: 07$ & $0.118(0.107)$ & $0.173(0.172)$ & 0.088 & 0.171 & $-0.016^{\circ}$ & $-0.031^{\circ}$ \\
\hline $84: 12-92: 10$ & $-0.068(-0.068)$ & $0.156(0.155)$ & 0.173 & 0.167 & $-0.226^{\circ}$ & $-0.219^{\circ}$ \\
\hline
\end{tabular}




Newsletier
Forecast
range
(after1. costs)

STOCK MARKET CYCLES

PROF. TIMING SERVICE (CASH ON SELL) NOURSE REPORT

MARKETARLAN-MODEL STOCK PORTFOLIO

NICHOLSON REPORT-MMII

PLALN TALK INVESTOR (HIGH RISK)

PLAN TALK INVESTOR-- 'PERSONAL BEST"

SYSTEMS \& FORECASTS-.MUTUAL FUND

GRANYULLE-INVESTORS

SWITCH FUND ADVISORY

INVESTOR'S INTELLIGENCE (SWITCH FUND)

INVESTOR'S WTIELLIGENCE

GRANVILE-TRADER'S

HOWARD RUFF'S RUFF TIMES

HOW ARD RUFF-OSH I

HUGH TECHNOLOGY GROWTH STOCKS (TDMING)

NAME UNKNOWN

ELLIOTT WAVE THEORIST (TRADERS)

MEDICAL TECHNOLOGY STOCK LETTER

MUTUAL FUND INVESTING (BALANCED GROW)

BOB BRLNKER'S MARKETTIMER-AGGRESSIVE

BOB BRINKER'S MARKETTLMER-SHORT ON SELL

DOW THEORY COMMENT-PRIMARY TREND

NOLLOAD FUND INVESTOR-WEALTH BUILDER

THE BIG PICTURE-MODEL PORTFOLIO

ADDISON REPORT-MONITORED SPECULATIVE

MARGO'S MARKET MONTTOR (MUTUAL FUND)

STOCKMARKET CYCLES-HOURLY FUND SWITCH

DOW THEORY COMMENT--SECONDARY TREND

FUNDLINE

MUTUAL FUND MONITOR--TRADERS

GARSIDE FORECAST (NO SHORTING)

GARSIDE FORECAST (SHORTING)

FLEUTY MONITOR-GROWTH PORTFOLIO

DONOGHUE'S MONEYLETTER -VENTURESOME

PUETZ INVESTMENT ALERT.-AGGRESSIVE

O'MALLEY'S FIDELITY WATCH

DVESTMENT HORIZONS

DOWSE MARKET LETTER--EQUITIES ALLOC.

PERSONAL FINANCE-ST MUTUAL FUND

PRIME INVESTMENT ALERT-EQUITY MODEL MUTUAL FUND SWITCH SERVICE

CABOT MARKET LETTER-MUTUAL FUND

PROF. TAPE READER (SHORT TERM. NO SHORT)

PROF. TAPE READER (SHORT TERM, SHORTING)

PROF. TAPE READER (INTERMED., SHORTING)

PROF. TAPE READER (INTERMED., NO SHORT)

GROWTH FUND GULDE--MUTUAL FUND ALLOC.

MUTUAL FUND FORECASTER

BI RESEARCH

PERSONAL FINANCE--GROWTH PORTFOLIO

PROF. TIMING SERVICE--MUTUAL FUND

MARKETARLAN-MUTUAL FUND TRADER

PROF. TAPE READER (LONG TERM. SHORTING)

PROF. TAPE READER (LONG TERM. NO SHORT)

\begin{tabular}{|c|c|c|c|c|c|c|}
\hline $84: 12-90: 11$ & $0.069(0.054)$ & $0.116(0.112)$ & 0.085 & 0.142 & $-0.046^{\circ}$ & $-0.074^{\circ}$ \\
\hline $85: 01-88: 12$ & $0.051(0.045)$ & $0.316(0.310)$ & 0.130 & 0.116 & $-0.303^{\circ}$ & $-0.262^{\circ}$ \\
\hline $85: 01-87: 01$ & $0.296(0.288)$ & $0.317(0.312)$ & 0.162 & 0.167 & $-0.021^{\circ}$ & $-0.017^{\circ}$ \\
\hline $85: 01-92: 12$ & $0.111(0.103)$ & $0.167(0.166)$ & 0.112 & 0.166 & $-0.033^{\circ}$ & $-0.049^{\circ}$ \\
\hline $85: 01-88: 08$ & $0.084(0.055)$ & $0.172(0.169)$ & 0.175 & 0.196 & $-0.107^{\circ}$ & $-0.118^{\circ}$ \\
\hline $85: 01-92: 12$ & $0.121(0.111)$ & $0.167(0.166)$ & 0.090 & 0.166 & $-0.011^{-}$ & $-0.020^{\circ}$ \\
\hline $85: 01-92: 12$ & $0.121(0.114)$ & $0.167(0.166)$ & 0.136 & 0.166 & $-0.036^{\circ}$ & $-0.044^{\circ}$ \\
\hline $85: 01-88: 01$ & $0.113(0.091)$ & $0.192(0.189)$ & 0.100 & 0.209 & $-0.038^{\circ}$ & $-0.082^{\circ}$ \\
\hline $85: 01-90: 12$ & $0.164(0.157)$ & $0.171(0.167)$ & 0.079 & 0.144 & $0.030^{\circ}$ & $0.059^{\circ}$ \\
\hline $85: 01-88: 11$ & $0.134(0.130)$ & $0.177(0.174)$ & 0.110 & 0.191 & -0.002 & -0.003 \\
\hline $85: 01-92: 12$ & $0.141(0.130)$ & $0.161(0.160)$ & 0.076 & 0.169 & $0.021^{\circ}$ & $0.051^{\circ}$ \\
\hline $85: 01$ & 0.09210 & 0.128 & 0.080 & 0.150 & $-0.025^{\circ}$ & $-0.045^{\circ}$ \\
\hline $85: 01-90: 12$ & $-0.049(-0.059)$ & $0.173(0.170)$ & 0.108 & 0.146 & -0.207 & $-0.274^{\circ}$ \\
\hline $85: 01-92: 12$ & $0.102(0.091)$ & $0.199(0.197)$ & 0.088 & 0.134 & $-0.061^{\circ}$ & $-0.095^{\circ}$ \\
\hline $85: 01-90: 12$ & $0.036(0.024)$ & $0.155(0.151)$ & 0.078 & 0.145 & $-0.095^{\circ}$ & $-0.171^{\circ}$ \\
\hline $85: 04-88: 12$ & $0.151(0.148)$ & $0.158(0.155)$ & 0.200 & 0.201 & $-0.010^{\circ}$ & $-0.006^{\circ}$ \\
\hline $85: 04-85: 11$ & $0.178(0.173)$ & $0.241(0.236)$ & 0.088 & 0.127 & $-0.016^{\circ}$ & $-0.011^{\cdots}$ \\
\hline $85: 12-92: 11$ & $-0.129(-0.148)$ & $0.148(0.147)$ & 0.188 & 0.174 & $-0.302^{\circ}$ & $-0.279^{\circ}$ \\
\hline $85: 12 \cdot 92: 07$ & $0.299(0.297)$ & $0.304(0.301)$ & 0.134 & 0.138 & 0.001 & $0.004^{\circ}$ \\
\hline $85: 12 \cdot 92: 12$ & $0.128(0.125)$ & $0.152(0.150)$ & 0.108 & 0.175 & $0.004^{\cdots}$ & $0.010^{\circ}$ \\
\hline $85: 1$ & 0.149 & 0.239 & 0.106 & 0.152 & $-0.049^{\circ}$ & $-0.070^{\circ}$ \\
\hline $85: 1$ & $0.162(0.162)$ & 0.5 & 0.183 & 0.131 & $-0.565^{\circ}$ & $-0.352^{\circ}$ \\
\hline $85: 12-86: 12$ & $0.139(0.133)$ & $0.185(0.175)$ & 0.170 & 0.179 & $-0.045^{\circ}$ & $-0.038^{\circ}$ \\
\hline $85: 12-92: 12$ & $0.100(0.098)$ & $0.124(0.122)$ & 0.161 & 0.181 & $-0.021^{\circ}$ & $-0.022^{\circ}$ \\
\hline $85: 12-92: 12$ & $0.152(0.147)$ & $0.201(0.199)$ & 0.125 & 0.174 & $-0.015^{\circ}$ & $-0.020^{\circ}$ \\
\hline $85: 12-92: 12$ & $0.117(0.109)$ & $0.144(0.143)$ & 0.143 & 0.172 & $-0.023^{\circ}$ & $-0.027^{\circ}$ \\
\hline $85: 12-92: 08$ & $0.129(0.112)$ & $0.134(0.132)$ & 0.107 & 0.177 & 0.003 & 0.006 \\
\hline $85: 12-90: 11$ & $0.046(0.019)$ & $0.128(0.126)$ & 0.139 & 0.189 & $-0.096^{\circ}$ & $-0.129^{\circ}$ \\
\hline $86: 01-87: 06$ & $0.221(0.198)$ & 0.31 & 0.111 & 0.178 & -0.020 & -0.028 \\
\hline $86: 0$ & 0.116 & $0.131(0.129)$ & 0.157 & 0.188 & $-0.025^{\circ}$ & $-0.028^{\circ}$ \\
\hline $86: 01-86: 02$ & 0.535 & $534)$ & 0.159 & 0.176 & $-0.015^{\circ}$ & $0.043^{\circ}$ \\
\hline $86: 12-92: 12$ & $0.129(0.113)$ & $0.132(0.130)$ & 0.070 & 0.173 & $0.020^{\circ}$ & $0.055^{\circ}$ \\
\hline $86: 12-92: 12$ & $0.020(0.020)$ & $0.132(0.130)$ & 0.177 & 0.173 & $-0.113^{\circ}$ & $-0.108^{\circ}$ \\
\hline $86: 12$ & 0.250 & 0.2 & 0.117 & 0.136 & -0.004 & -0.001 \\
\hline $86: 12-92: 12$ & 0.1131 & 0.143 ) & 0.150 & 0.172 & $-0.028^{\circ}$ & $-0.030^{\circ}$ \\
\hline $86: 12-88: 09$ & $0.158(0.147)$ & $0.106(0.100)$ & 0.201 & 0.237 & 0.045 & 0.059 \\
\hline $86: 12-87: 10$ & $0.081(0.081)$ & $0.081(0.069)$ & 0.312 & 0.312 & 0.000 & 0.012 \\
\hline $86: 12-92: 12$ & $0.124(0.121)$ & $0.210(0.208)$ & 0.094 & 0.171 & $-0.023^{\circ}$ & $-0.044^{\circ}$ \\
\hline $86: 12-88: 11$ & $0.098(0.092)$ & $0.161(0.156)$ & 0.211 & 0.221 & $-0.065^{\circ}$ & $-0.064^{\circ}$ \\
\hline $86: 12-92: 12$ & $0.108(0.090)$ & $0.123(0.121)$ & 0.150 & 0.181 & $-0.025^{\circ}$ & $-0.028^{\prime}$ \\
\hline$: 07$ & 0.084 & 0.1 & 0.165 & 0.195 & & \\
\hline $86: 1$ & 0.077 & 0.1 & & & -0 & $04^{*}$ \\
\hline $86: 12-89: 08$ & $0.179(0.170)$ & $0.204(0.199)$ & 0.172 & 0.222 & -0.006 & -0.004 \\
\hline $86: 12-92: 12$ & $0.091(0.061)$ & $0.152(0.150)$ & 0.131 & 0.179 & $-0.069^{\circ}$ & $-0.094^{\circ}$ \\
\hline $86: 12-92: 12$ & $-0.061(-0.061)$ & $0.152(0.150)$ & 0.184 & 0.179 & $-0.215^{\circ}$ & $-0.207^{\circ}$ \\
\hline $86: 12-92: 03$ & $0.105(0.105)$ & $0.180(0.176)$ & 0.226 & 0.222 & $-0.077^{\circ}$ & $-0.072^{*}$ \\
\hline $86: 12-92: 03$ & $0.1640 .137)$ & $0.180(0.176)$ & 0.197 & 0.222 & $-0.032^{\circ}$ & $-0.032^{\cdots}$ \\
\hline $86: 12-92: 12$ & $0.078(0.075)$ & $0.159(0.157)$ & 0.131 & 0.175 & $-0.062^{\circ}$ & $-0.083^{\circ}$ \\
\hline $86: 12 \cdot 92: 12$ & $0.127(0.127)$ & $0.145(0.142)$ & 0.185 & 0.196 & $-0.014^{\circ}$ & $-0.012^{\circ}$ \\
\hline $86: 12 \cdot 92: 12$ & $0.177(0.172)$ & $0.206(0.204)$ & 0.109 & 0.142 & 0.000 & 0.001 \\
\hline $86: 12$ & 0.18 & 0.1 & 0.158 & & -0. & $-0.007^{\circ}$ \\
\hline $87: 01-92: 12$ & $0.071(0.052)$ & $0.158(0.156)$ & 0.085 & 0.169 & $-0.060^{\circ}$ & $-0.122^{\circ}$ \\
\hline $87: 01-92: 12$ & $0.028(0.013)$ & $0.145(0.143)$ & 0.134 & 0.177 & $-0.114^{\circ}$ & $-0.150^{\circ}$ \\
\hline $87: 01-92: 08$ & $-0.125(-0.125)$ & $0.217(0.214)$ & 0.203 & 0.195 & $-0.347^{\circ}$ & $-0.332^{\circ}$ \\
\hline $87: 01-92: 08$ & $0.065(0.052)$ & $0.217(0.214)$ & 0.165 & 0.195 & $-0.142^{\circ}$ & $-0.168^{\circ}$ \\
\hline
\end{tabular}




\begin{tabular}{|c|c|c|c|c|c|c|}
\hline $\begin{array}{c}\text { Forecast } \\
\text { rngee }\end{array}$ & $\begin{array}{l}\text { Newsletter } \\
\text { rewirn } \\
\text { (aftert.cosis) }\end{array}$ & $\begin{array}{c}\text { SeP s00 } \\
\text { reuirn } \\
\text { (after }, \text { costs) }\end{array}$ & $\begin{array}{l}\text { Newsletuer } \\
\text { yolatility }\end{array}$ & $\begin{array}{l}\text { Sec } 500 \\
\text { yolatility }\end{array}$ & $\begin{array}{c}\text { Measure } 1 \\
\text { abnormal } \\
\text { cetumen }\end{array}$ & $\begin{array}{c}\text { Mezsure } 2 \\
\text { abnormal } \\
\text { cerum }\end{array}$ \\
\hline $87: 01-92: 12$ & $0.079(0.075)$ & $0.118(0.116)$ & 0.091 & 0.165 & $-0.021^{\circ}$ & $-0.052^{\circ}$ \\
\hline $87: 01-92: 12$ & $0.079(0.074)$ & $0.118(0.116)$ & 0.083 & 0.165 & $-0.019^{\circ}$ & $-0.051^{\circ}$ \\
\hline $87: 01-92: 12$ & $0.149(0.137)$ & $0.118(0.116)$ & 0.104 & 0.165 & $0.03 T$ & $0.063^{\circ}$ \\
\hline $87: 0 \div-92: 12$ & $0.168(0.148)$ & $0.168(0.166)$ & 0.095 & 0.136 & 0.011 & 0.018 \\
\hline $87: 01-91: 06$ & $0.092(0.072)$ & $0.164(0.161)$ & 0.174 & 0.208 & $-0.079^{\circ}$ & $-0.092^{\circ}$ \\
\hline $87: 01-88: 01$ & $0.499(0.496)$ & $0.582(0.571)$ & 0.120 & 0.145 & $0.018^{\circ}$ & $0.034^{\circ}$ \\
\hline $87: 01-92: 12$ & $0.138(0.120)$ & $0.211(0.208)$ & 0.087 & 0.158 & $-0.023^{\circ}$ & $-0.040^{\circ}$ \\
\hline $87: 01-92: 12$ & $0.040(0.026)$ & $0.151(0.149)$ & 0.077 & 0.171 & $-0.078^{\circ}$ & $-0.173^{\circ}$ \\
\hline $87: 01-92: 12$ & $0.010(-0.007)$ & $0.140(0.138)$ & 0.279 & 0.171 & $-0.177^{\circ}$ & $-0.105^{\circ}$ \\
\hline $87: 01-92: 12$ & $0.186(0.129)$ & $0.140(0.138)$ & 0.608 & 0.171 & 0.032 & $-0.032^{\circ}$ \\
\hline $87: 01-90: 08$ & $0.060(0.033)$ & $0.119(0.116)$ & 0.250 & 0.195 & $-0.091^{\circ}$ & $-0.069^{\circ}$ \\
\hline $87: 01-87: 09$ & $0.226(0.203)$ & $0.596(0.572)$ & 0.053 & 0.192 & 0.018 & 0.111 \\
\hline $87: 12-92: 07$ & $-0.019(-0.025)$ & $0.158(0.155)$ & 0.118 & 0.146 & $-0.166^{\circ}$ & $-0.202^{\circ}$ \\
\hline $87: 12-92 ; 07$ & $0.008(-0.002)$ & $0.158(0.155)$ & 0.127 & 0.146 & $-0.148^{\circ}$ & $-0.167^{\circ}$ \\
\hline $87: 12-92: 07$ & $0.024(0.010)$ & $0.252(0.246)$ & 0.081 & 0.140 & $-0.156^{\circ}$ & $-0.268^{\circ}$ \\
\hline $87: 12-92: 07$ & $-0.224(-0.224)$ & $0.252(0.246)$ & 0.139 & 0.140 & $-0.474^{\circ}$ & $-0.472^{\circ}$ \\
\hline $87: 12-92: 08$ & $0.109(0.076)$ & $0.146(0.144)$ & 0.081 & 0.138 & $-0.037^{\circ}$ & $-0.064^{\circ}$ \\
\hline $87: 12-88: 07$ & $0.039(0.024)$ & $0.222(0.205)$ & 0.018 & 0.102 & $-0.061^{\circ}$ & $-0.318^{\circ}$ \\
\hline $87: 12-92: 11$ & $0.141(0.128)$ & $0.144(0.142)$ & 0.113 & 0.136 & -0.003 & -0.002 \\
\hline $87: 12-88: 11$ & $0.162(0.162)$ & $0.162(0.151)$ & 0.105 & 0.105 & 0.000 & 0.011 \\
\hline $87: 12-92: 12$ & $0.134(0.129)$ & $0.190(0.188)$ & 0.091 & 0.135 & $-0.019^{\prime}$ & $-0.028^{\circ}$ \\
\hline $87: 12-92: 12$ & $0.099(0.093)$ & $0.209(0.206)$ & 0.044 & 0.122 & $-0.020^{\circ}$ & $-0.060^{\circ}$ \\
\hline $87: 12-89: 12$ & $0.209(0.203)$ & $0.239(0.234)$ & 0.089 & 0.112 & -0.001 & 0.003 \\
\hline $87: 12-92: 12$ & $0.142(0.131)$ & $0.166(0.164)$ & 0.100 & 0.138 & -0.006 & -0.007 \\
\hline $87: 12-92: 12$ & 0.132 & $0.168(0.166)$ & 0.070 & 0.137 & $0.011^{\circ}$ & $0.024^{\circ}$ \\
\hline $87: 12-88: 10$ & 0.191 & 0.200 & 0.104 & 0.106 & $-0.015^{\circ}$ & -0.003 \\
\hline $87: 12-90: 12$ & $0.021(0.003)$ & $0.066(0.061)$ & 0.086 & 0.148 & $-0.067^{\circ}$ & $-0.109^{\circ}$ \\
\hline $87: 12-90: 04$ & $0.044(0.039)$ & $0.082(0.073)$ & 0.038 & 0.121 & $-0.033^{\circ}$ & $-0.094^{\circ}$ \\
\hline $88: 01-92: 12$ & $0.151(0.149)$ & $0.204(0.202)$ & 0.085 & 0.125 & $0.008^{\circ}$ & $-0.012^{\circ}$ \\
\hline $88: 01-92: 12$ & $0.139(0.134)$ & $0.197(0.194)$ & 0.093 & 0.134 & $-0.022^{\circ}$ & $-0.030^{\circ}$ \\
\hline 88:01-90:08 & $0.034(0.027)$ & $0.056(0.049)$ & 0.098 & 0.158 & $-0.036^{\circ}$ & $-0.050^{\circ}$ \\
\hline $88: 01-92: 12$ & $0.112(0.101)$ & $0.159(0.157)$ & 0.090 & 0.134 & $-0.028^{\circ}$ & $-0.041^{\circ}$ \\
\hline $88: 01-88: 12$ & $0.134(0.125)$ & $0.168(0.158)$ & 0.087 & 0.101 & $-0.029^{\circ}$ & $-0.023^{\circ}$ \\
\hline $88: 01-92: 12$ & $-0.040 \times-0.040)$ & $0.159(0.157)$ & 0.141 & 0.134 & $-0.204^{\circ}$ & $-0.192^{\circ}$ \\
\hline $88: 01-92: 12$ & $0.100 x$ & $0.159(0.157)$ & 0.085 & 0.134 & $-0.058^{\circ}$ & $-0.091^{\circ}$ \\
\hline 88:01-92:12 & $-0.041(-0.041)$ & $0.147(0.1+6)$ & 0.139 & 0.133 & $-0.192^{\circ}$ & $-0.181^{\circ}$ \\
\hline 88:01-88:07 & $-0.071(-0.118)$ & $0.222(0.205)$ & 0.067 & 0.102 & $-0.281^{\circ}$ & $-0.405^{\circ}$ \\
\hline $88: 01-92: 12$ & $0.078(0.039)$ & $0.159(0.157)$ & 0.093 & 0.134 & $-0.092^{\circ}$ & $-0.131^{\circ}$ \\
\hline $88: 01-92: 12$ & $0.109(0.096)$ & $0.147(0.145)$ & 0.107 & 0.135 & $-0.034^{\circ}$ & $-0.042^{\circ}$ \\
\hline 88:01-92:07 & $0.133(0.106)$ & $0.182(0.180)$ & 0.123 & 0.142 & $-0.061^{\circ}$ & $-0.069^{\circ}$ \\
\hline 88:01-92:07 & $0.041(0.038)$ & $0.182(0.180)$ & 0.149 & 0.142 & $-0.149^{\circ}$ & $0.141^{\circ}$ \\
\hline $88: 12-92: 12$ & 0.379 & $0.240(0.235)$ & 0.218 & 0.128 & -0.001 & 0.003 \\
\hline $88: 12$ & 0.07 & $0.205(0.201)$ & 0.049 & 0.153 & $-0.052^{\circ}$ & $-0.164^{\circ}$ \\
\hline $88: 12-92: 01$ & $0.180(0.179)$ & $0.327(0.322)$ & 0.066 & 0.134 & $-0.013^{\circ}$ & $-0.025^{\circ}$ \\
\hline $88: 12-92: 12$ & 0.189 & $0.278(0.274)$ & 0.104 & 0.131 & $-0.047^{\circ}$ & $-0.059^{\circ}$ \\
\hline $88: 12-92: 12$ & $0.192(0.186)$ & $0.266(0.262)$ & 0.108 & 0.136 & $-0.036^{\circ}$ & $-0.043^{\circ}$ \\
\hline $88: 12-92: 12$ & $0.093(0.069)$ & $0.156(0.153)$ & 0.079 & 0.148 & $-0.046^{\circ}$ & $-0.086^{\prime \prime}$ \\
\hline $88: 12-90: 04$ & $0.039(0.033)$ & $0.055(0.040)$ & 0.146 & 0.148 & $-0.022^{-}$ & $-0.008^{\circ}$ \\
\hline $88: 12-92: 12$ & $0.114(0.110)$ & $0.170(0.167)$ & 0.100 & 0.145 & $-0.028^{\circ}$ & $-0.039^{\circ}$ \\
\hline $88: 12-92: 12$ & $0.114(0.109)$ & $0.157(0.155)$ & 0.116 & 0.142 & $-0.031^{\circ}$ & $-0.037^{\circ}$ \\
\hline $88: 12-92: 12$ & $0.058(0.049)$ & $0.224(0.219)$ & 0.083 & 0.139 & $-0.105^{\circ}$ & $-0.179^{\circ}$ \\
\hline $88: 12-92: 12$ & $0.043(0.011)$ & $0.157(0.155)$ & 0.132 & 0.142 & $-0.140^{\circ}$ & $-0.149^{\circ}$ \\
\hline $88: 12-92: 12$ & $0.261(0.248)$ & $0.180(0.177)$ & 0.230 & 0.144 & 0.008 & 0.005 \\
\hline $88: 12-90: 05$ & $0.227(0.221)$ & $0.243(0.236)$ & 0.109 & 0.154 & 0.025 & 0.043 \\
\hline
\end{tabular}

EQUALLY WEIGHTED LETTER (Posi-1986) EQUALLY WEIGHTED LETTER (POSt-' 86 : $>4$ yrs) STATISTICAL MODEL (Post-1986)

STATISTICAL MODEL (Post-1986, except Oct. 87)

VOLUME REVERSAL SURVEY-INDEX PORT. NEW MUTUAL FUND ADVISOR-GROWTH SWITCH FUND TDMING-CONSERVATTVE SWITCH FUND TDMING-MODEL STOCK PORT. SECTOR FUNDS NEWSLETTER-MODEL PORT. WALI STREET GENERALIST-SELECT TRADING VOLUME REVERSAL SURVEY-TTMING ONLY TTA MUTUAL FUND ADVISOR-GROWTH DINES LETTER-INTERMED. TREND (SHORTING) DINES LETTER-INTERMED. TREND (NO SHORT)

DINES LETTER-LONG TERM-NO SHORTING DINES LETTER-LONG TERM-SHORTING FUTURES HOTLINE-STOCK MUTUAL FUND b ARMONIC RESEARCH (NO SHORTING)

IHE BIG PICTURE (MASTER KEY-NO SHORT) THE BIG PICTURE-MASTER TECH. (SHORTING) KINSMAN'S LOW-RISK GROWTH LETTER NEY MUTUAL FUND REPORT--GROWTH PORT. PERSONAL PORTFOLIO MANAGER WALI STREET DIGEST STOCX AND BOND PORT

LALOGGIA SPECIAL SITUATION REPORT FWELTTY MONTTOR-GROWTH PORTFOLIO MARGO-MUTUAL FUND PORTFOLIO NEY-GROWTH FUND PORTFOLIO

CLEAN YIELD-MODEL PORTFOLIO FWELITY INSIGHT-GROWTH PORTFOLIO FIDELTTY INSIGHT

ADDISON REPORT-MUTUAL FUND ALLOC. HIGH TECHNOLOGY GROWTH STOCKS TIMER DIGEST.- "CASPER" (SHORTING)

TIMER DIGEST- " CASPER" (NO SHORTING) FUTURES HOTLINE--INTERKEDLATE TERM HARMONIC RESEARCH (SHORTING)

GRAPHIC FUNDS-GROWTH/INT'L PORTFOLIO WEBER'S FUND ADVISOR

TDMER DIGEST-." ' \& 10 CONSEN." (NO SHORT) TTMER DIGEST- $"$ ' \& \& 10 CONSEN." (SHORTING) THE PRUDENT SPECULATOR

BOB NUROCX'S ADVISORY-SECTOR FUND INV BLUE CHIP VALUES-.GROWTH PORTFOLIO

CABOT'S FUND NAVIGATOR-GROWTH \& INC CABOT'S FUND NAVIGATOR-GROWTH PORT. CHARTIST MUTUAL FUND TIMER COLONY GROUP INVESTMENT LETTER DONOGHUE'S MONEYLETTER-CONSER VATIVE DONOGHUE'S MONEYLETTER-ACTIVE MODEL DONOGHUE'S MONEYLETTER-SIGNAL PORT FAST TRACK FUNDS MEDICAL TECH. STOCK LETTER--AGGRESSIVE SECTOR LNVESTOR--.MODEL PORTFOLIO 
WALL ST. GENERALIST-ST INDIC. (NO SHORT) WALI ST GENERALIST-ST INDICATOR (SHORT) BOB NUROCK'S ADVISORY-ELVES ST (SHORTS) BOB NUROCX'S ADVISORY-ELVES ST (NO SHRT) CRAWFORD PERSPECTIVES-NO SHORTING PAD SYSTEM REPORT-AGGRESSIVE PORT INVESTOR'S GUIDE TO CLOSED-END FUNDS WALL ST. GENERALIST-TOP TRENDS (NO SHRT) WALL ST. GENERALIST -TOP TRENDS (SHORTS)

CABOT'S MUTUAL FUND NAVIGATOR-INCOME WALL STREET GENERALIST--LONG-TERM FUND WALL STREET GENERALIST-INTERMED. FUND BOB NUROCK'S ADVISORY-INDEX FUND CRAWFORD PERSPECTIVES-100\% SHRT ON SELL WALL STREET GENERALIST-SELECT INTER. AGBIOTECH STOCK LETTER-MODEL PORT. HOWARD RUFF'S RUFF TLMES-OSH PORT. KEN GERBINO INVESTMENT LETTER LG NO LOAD FUND ANALYST--PORTFOLIO A

UG NO LOAD FUND ANALYST.-PORTFOLIO B 1 IUTUAL FUND INVESTLNG--MAX. GROWTH 1.O LOAD SELECT./TIMING: INTER. (SHORTS) NO LOAD SELECT./TMING: INTER (NO SHORT) N. L. SELECT./TLMING: PRIMARY (SHORT) N. L. SELECT./TIMING: PRIMARY (NO SHRT) N. L. SELECT. TTMING: INTERM. TERM PORT OVERPRICED STOCK SERVICE

PRICE TREND-TECH. TRENDS (NO SHORTING) PRICE TREND-TECH. TRENDS (SHORTING)

PRICE TREND (NO SHORTING) PRICE TREND (SHORTING) PRICE TREND-MODEL PORTFOLJO SCOTT LETTER-EQLITY PORTFOLIO SWITCH FUND TIMING-CONSERVATIVE HOWARD RUFF--OSH 2

INVESTOR'S GUIDE/CLOSED-END FUNDS: ॥ SY HARDING INVESTOR FCR CCASTS-PORT. I THE CHARTIST MUTUAL FUND TLMER SY HARDING-.MUTUAL FUND PORT.

LYNN ELGERT LETTER--MUTUAL FUND ALLOC. INVESTORS INTELLIGENCE--LONG-TERM STOCK SY HARDING INVESTOR FORECASTS--PORT. I INVESTORS INTELLIGE.NCE--LOW-PRICED STO P.Q. WALL FORECAST

MARKET MANLA-LONG TERM MUTUAL FUND SY HARDING LNVESTOR FORECASTS--PORT 3 DOW THEORY FORECASTS--EQUITY ALLOC CABOT MKT. LETTER-CONSERVATIVE GROWTH LYNN ELGERT LETTER--TRADERS STOCK PORT.

BIG PICTURE-MONETARY FORC. (NO SHORT) THE BIG PICTURE--MONETARY FORC. (SHORTS) INVESTOR'S GUIDE / CLOSED-END FUNDS-II INVESTOR'S GUIDE CLOSED.END FUNDS-IV RETIREMENT LETTER $\begin{array}{llll}88: 12-89: 05 & 0.204(0.204) & 0.460(0.436) & 0.167\end{array}$ $\begin{array}{lllll}88: 12-89: 05 & 0.353(0.337) & 0.460(0.436) & 0.133\end{array}$ $\begin{array}{lllll}88: 12-92: 10 & -0.117(-0.118) & 0.169(0.165) & 0.148\end{array}$ $88: 12-92: 10 \quad 0.062(0.048) \quad 0.168(0.165) \quad 0.102$ $\begin{array}{lllll}88: 12-92: 07 & 0.071(0.049) & 0.163(0.160) & 0.123\end{array}$ $88: 12-92: 12 \quad 0.134(0.130) \quad 0.141(0.138) \quad 0.106$ $\begin{array}{llll}89: 01-92: 12 & 0.133(0.127) & 0.157(0.155) & 0.109\end{array}$ $\begin{array}{llll}89: 01-89: 06 & 0.052(0.023) & 0.356(0.336) & 0.06\end{array}$ $\begin{array}{llll}89: 01-89: 06 & -0.282(-0.290) & 0.356(0.336) & 0.129\end{array}$

89:01.92:12 $0.134(0.128) \quad 0.225(0.221) \quad 0.101$ 89.01.92:08 $0.143(0.140) \quad 0.159(0.156) \quad 0.127$ $\begin{array}{llll}89: 01-92: 10 & 0.121(0.116) & 0.136(0.133) & 0.125\end{array}$ $\begin{array}{lllll}89: 01-92: 12 & 0.101(0.089) & 0.193(0.196) & 0.076\end{array}$ $89.01-92.12-0.02(-0.011) \quad 0.157(0.155) 0.133$ $\begin{array}{lllll}89: 12-92: 12 & 0.121(0.117) & 0.120(0.113) & 0.135\end{array}$ $\begin{array}{lllll}89: 12-92: 12 & 0.0+4(0.032) & 0.108(0.105) & 0.086\end{array}$ $89: 12-91: 07 \quad 0.110(0.104) \quad 0.088(0.092) \quad 0.124$ $89: 12-92: 12 \quad 0.147(0.146) \quad 0.144(0.138) \quad 0.135$

$\begin{array}{lllll}89: 12-92: 12 & 0.092(0.091) & 0.093(0.086) & 0.122\end{array}$ $89: 12-92: 12 \quad 0.117(0.114) \quad 0.116(0.112) \quad 0.15$ $89: 12-92: 12 \quad 0.087(0.062) \quad 0.108(0.105) \quad 0.136$ $\begin{array}{lllll}89: 12-92: 11 & 0.111(0.074) & 0.107(0.104) & 0.096\end{array}$ $89: 12-92: 12 \quad-0.076(-0.093) \quad 0.124(0.120) \quad 0.121$ $\begin{array}{lllll}89: 12-92: 04 & -0.022(-0.037) & 0.147(0.140) & 0.094\end{array}$ $89: 12-92: 12 \quad 0.132(0.105) \quad 0.108(0.105) \quad 0.077$ $89: 12-91: 06 \quad 0.061(0.048) \quad 0.070(0.063) \quad 0.144$ $89: 12.91: 07 \quad 0.039(0.023) \quad 0.098(0.092) \quad 0.149$ $\begin{array}{llllll}89: 12-91: 07 & -0.070(-0.070) & 0.098(0.092) & 0.172\end{array}$

89:12-91:07 $0.021(-0.001) \quad 0.098(0.092) \quad 0.123$ $\begin{array}{lllll}89: 12.91: 07 & -0.123(-0.126) & 0.098(0.092) & 0.170\end{array}$ 89: $12-91: 07 \quad 0.005(-0.009) \quad 0.110(0.103) \quad 0.283$ 89:12-90:08 $-0.030(-0.040)-0.096(-0.111) \quad 0.166$ $89: 12-92: 12 \quad 0.146(0.129) \quad 0.116(0.112) \quad 0.094$ $89: 12-90: 12 \quad-0.069(-0.081) \quad-0.032(-0.042) \quad 0.087$ $\begin{array}{llllll}90.01 .92: 12 & 0.088(0.0777 & 0.108(0.105) & 0.101\end{array}$ $\begin{array}{lllll}90: 01-92: 12 & 0.096(0.074) & 0.108(0.105) & 0.077\end{array}$ $\begin{array}{lllll}90: 01-90: 12 & 0.078(0.074) & -0.032(-0.042) & 0.005\end{array}$ $90: 01-90: 12 \quad 0.074(0.045) \quad-0.032(-0.042) \quad 0.085$

$\begin{array}{llll}90: 01-91: 10 & 0.075(0.062) & 0.062(0.052) & 0.036\end{array}$ $90.01 .92 .12 \quad 0.1400 .132) \quad 0.108(0.105) \quad 0.094$ $90: 01-92: 12 \quad 0.057(0.044)$ $90: 01-92: 12 \quad 0.094(0.090)$ $90: 01-92: 12-0.073(-0.089)$

90:01.92:10 $0.104(0.101)$

$0.115(0.115) \quad 0.106$ $\begin{array}{lllll}90: 01-92: 12 & 0.085(0.072) & 0.108(0.105) & 0.049\end{array}$ $90: 01-91: 01 \quad-0.121(-0.131) \quad-0.051(-0.062) \quad 0.146$ $0.01-92: 12 \quad 0.103(0.099) \quad 0.105(0.101) \quad 0.127$ $\begin{array}{lllll}90: 01-91: 11 & 0.027(0.019) & 0.068(0.063) & 0.037\end{array}$

$\begin{array}{llll}90: 12-91: 09 & 0.282(0.282) & 0.282(0.269) & 0.125\end{array}$ $\begin{array}{lllll}90: 12-91: 09 & 0.282(0.282) & 0.282(0.269) & 0.125\end{array}$ $90: 12.92: 12 \quad 0.143(0.136) \quad 0.186(0.181) \quad 0.076$ $90: 12-92: 12 \quad 0.154(0.147) \quad 0.186(0.181) \quad 0.084$ $\begin{array}{lllll}90: 12.91: 12 & 0.241(0.240) & 0.305(0.295) & 0.118\end{array}$

\begin{tabular}{|c|c|c|}
\hline 0.127 & $-0.393^{\circ}$ & $-0.260^{\circ}$ \\
\hline 0.127 & $-0.144^{\circ}$ & $-0.111^{\circ}$ \\
\hline 0.145 & $-0.288^{\circ}$ & $-0.279^{\circ}$ \\
\hline 0.145 & $-0.089^{\circ}$ & $-0.127^{\circ}$ \\
\hline 0.148 & $-0.099^{\circ}$ & $-0.117^{\circ}$ \\
\hline 0.145 & $0.010^{-}$ & $0.016^{\circ}$ \\
\hline 0.142 & $-0.009^{\circ}$ & $-0.010^{\circ}$ \\
\hline 0.126 & $-0.187^{\circ}$ & $-0.379^{\circ}$ \\
\hline 0.126 & $-0.653^{\circ}$ & $-0.618^{\circ}$ \\
\hline 0.138 & $-0.052^{\circ}$ & $-0.071^{\circ}$ \\
\hline 0.148 & $-0.006^{\circ}$ & $-0.004^{\circ}$ \\
\hline 0.146 & $-0.010^{\circ}$ & $-0.009^{\circ}$ \\
\hline 0.141 & $-0.044^{\circ}$ & $-0.082^{\circ}$ \\
\hline 0.142 & $-0.162^{\circ}$ & $-0.171^{\circ}$ \\
\hline 0.143 & $-0.025^{\circ}$ & $-0.019^{\circ}$ \\
\hline 0.133 & $-0.004^{\circ}$ & $0.004^{\circ}$ \\
\hline 0.147 & $-0.05 T$ & $-0.095^{\circ}$ \\
\hline 0.170 & 0.011 & 0.020 \\
\hline 0.144 & $0.008^{\circ}$ & $0.014^{\circ}$ \\
\hline 0.132 & 0.001 & $0.009^{\circ}$ \\
\hline 0.152 & -0.002 & 0.002 \\
\hline 0.147 & -0.043 & -0.044 \\
\hline 0.149 & -0.017 & -0.024 \\
\hline 0.157 & $-0.203^{\circ}$ & $-0.256^{\circ}$ \\
\hline 0.187 & $-0.146^{\circ}$ & $-0.275^{\circ}$ \\
\hline 0.147 & $0.020^{\circ}$ & $0.041^{\circ}$ \\
\hline 0.172 & -0.024 & 0.022 \\
\hline 0.170 & $-0.073^{\circ}$ & $-0.077^{\circ}$ \\
\hline 0.170 & $-0.168^{\circ}$ & $-0.161^{\circ}$ \\
\hline 0.170 & $-0.094^{\circ}$ & $-0.124^{\circ}$ \\
\hline 0.170 & $-0.224^{\circ}$ & $-0.217^{\circ}$ \\
\hline 0.171 & $-0.126^{\circ}$ & $-0.072^{\circ}$ \\
\hline 0.200 & $0.026^{\circ}$ & $0.045^{\circ}$ \\
\hline 0.152 & $0.034^{\circ}$ & $0.060^{\circ}$ \\
\hline 0.184 & $-0.109^{\circ}$ & $0.200^{\circ}$ \\
\hline 0.147 & $-0.017^{\circ}$ & $-0.022^{*}$ \\
\hline 0.147 & -0.011 & -0.020 \\
\hline 0.184 & -0.002 & $-0.07 !$ \\
\hline 0.184 & 0.015 & 0.041 \\
\hline 0.157 & -0.007 & -0.026 \\
\hline 0.147 & $0.040^{\circ}$ & $0.068^{\circ}$ \\
\hline 0.147 & $-0.036^{\circ}$ & $-0.085^{\circ}$ \\
\hline 0.147 & $-0.009^{\circ}$ & $-0.009^{\circ}$ \\
\hline 0.147 & $-0.191^{\circ}$ & $-0.215^{\circ}$ \\
\hline 0.152 & 0.001 & 0.006 \\
\hline 0.147 & -0.003 & -0.009 \\
\hline 0.186 & $-0.109^{\circ}$ & $-0.122^{\circ}$ \\
\hline 0.146 & 0.000 & 0.003 \\
\hline 0.159 & $-0.051^{\circ}$ & $-0.200^{\circ}$ \\
\hline 0.125 & 0.000 & 0.013 \\
\hline 0.125 & 0.000 & 0.013 \\
\hline 0.124 & $0.006^{\cdots}$ & $0.013^{*}$ \\
\hline 0.124 & 0.007 & $0,015^{* *}$ \\
\hline 0.158 & 0.000 & $0.009^{\circ}$ \\
\hline
\end{tabular}


Invesoment newslener

EQUITY FUND OUTLOOK-AGRESSIVE PQ WALL--MUTUAL FUND MODEL MUTUAL FUND TECH. TRADER-AGRESSIVE THE BIG PICTURE-MASTER KEY-SHORTING HUSSMAN-MUTUAL FUND

RICHARD BAND'S PROFTTABLE INVESTING CZESCHD'S MUTUAL FUND OUTLOOK CONTRARIAN'S VIEW.-TLANCREF SWITCH PL GLOBAL FUND TIMER --U.S. PORTFOLIO FUNDLINE-TIMLNG PORTFOLIO

PQ WALL-STOCK TIMING MODEL LYNN ELGERT LETTER-INVESTORS STOCKS BLUE CHIP CORRELATOR NO LOAD PORFOLIOS--AGGRESSIVE GROWTH FUND KINETICS

NATIONAL TRENDLINES-STOCK TIMING TODD MARKET TDMER-STOCK FUND TIMING FINANCLAL PREDICTIONS-CONSERVATIVE FINANCLAL PREDICTIONS--SPECULATIVE PORT TOP PERFORMING STOCK OUTLOOK

VANGUARD ADVISOR-AGGRESSIVE GROWTH CLOSED END FUND DIGEST_-GLOBAL GROWTH ASSET ALLOCATER

US INVESTMENT REPORT-AGGRESSIVE GROWTH FUND PROFIT ALERT

US INVESTMENT REPORT--GROWTH PORTFOLIO

$Y$ HARDLNG INVESTOR FORECASTS-EQUITIES

Percent posidive:

Percent greater than .025:

Post-1986. percent positive:

Post-1986, percent greater than .025:

\begin{tabular}{|c|c|c|c|c|c|c|}
\hline $\begin{array}{c}\text { Forecast } \\
\text { Enge }\end{array}$ & $\begin{array}{l}\text { Newslewer } \\
\text { rewm } \\
\text { (after. costs) }\end{array}$ & $\begin{array}{c}\text { Sep } 500 \\
\text { reaura } \\
\text { (after l_costs) }\end{array}$ & $\begin{array}{l}\text { Newsienter } \\
\text { in yolatilixy }\end{array}$ & $\begin{array}{l}\text { SeP S00 } \\
\text { volntility }\end{array}$ & $\begin{array}{c}\text { Measure | } \\
\text { aboormal } \\
\text { retum }\end{array}$ & $\begin{array}{c}\text { Measure } 2 \\
\text { abnomial } \\
\text { rerum }\end{array}$ \\
\hline $0: 12-92: 12$ & $0.183(0.178)$ & $0.186(0.181)$ & 0.123 & 0.124 & $-0.006^{\circ}$ & -0.001 \\
\hline $90: 12-92: 05$ & $0.039(0.014)$ & $0.2140 .20 m$ & 0.070 & 0.140 & $-0.117^{\circ}$ & $-0.234^{\circ}$ \\
\hline $90: 12.92: 12$ & $0.155(0.147)$ & $0.186(0.181)$ & 0.133 & 0.124 & $-0.048^{\circ}$ & $-0.040^{\circ}$ \\
\hline $90: 12-92: 11$ & $0.141(0.124)$ & $0.186(0.181)$ & 0.122 & 0.127 & $-0.05 \%$ & $-0.054^{\circ}$ \\
\hline $91: 01 \cdot 92: 12$ & $0.253(0.238)$ & $0.186(0.181)$ & 0.165 & 0.124 & 0.008 & $0.010^{*}$ \\
\hline $91: 01-92: 12$ & $0.125(0.123)$ & $0.129(0.124)$ & 0.091 & 0.103 & $0.004^{\circ}$ & $0.009^{\circ}$ \\
\hline $1: 01-92: 12$ & $0.086(0.072)$ & $0.186(0.181)$ & 0.068 & 0.124 & $-0.049^{\circ}$ & $-0.090^{\circ}$ \\
\hline $1: 01-92: 12$ & $0.143(0.121)$ & $0.186(0.181)$ & 0.081 & 0.124 & -0.015 & $-0,020$ \\
\hline$: 01-92: 12$ & $0.114(0.090)$ & $0.186(0.181)$ & 0.067 & 0.124 & $-0.030^{\circ}$ & $-0.056^{\circ}$ \\
\hline $1: 01-92: 12$ & $0.155(0.140)$ & $0.186(0.181)$ & 0.096 & 0.124 & $-0.013^{*}$ & $-0.014^{\cdots}$ \\
\hline$: 01-92: 11$ & $-0.081(-0.093)$ & $0.186(0.181)$ & 0.118 & 0.127 & $-0.269^{\circ}$. & $-0.285^{\circ}$ \\
\hline $91: 01-91: 11$ & $0.103(0.092)$ & $0.189(0.178)$ & 0.054 & 0.129 & $-0.020^{\circ}$ & $-0.041^{+}$ \\
\hline $1: 01-92: 12$ & $0.151(0.145)$ & $0.186(0.181)$ & 0.088 & 0.124 & 0.001 & 0.005 \\
\hline$: 01.92: 12$ & $0.109(0.100)$ & $0.186(0.181)$ & 0.079 & 0.124 & $-0.034^{\circ}$ & $-0.051^{\circ}$ \\
\hline $1: 12.92: 12$ & $0.077(0.076)$ & $0.077(0.067)$ & 0.074 & 0.074 & $-0.001^{\circ}$ & $0.009^{\circ}$ \\
\hline $1: 12.92: 11$ & $0.111(0.099)$ & $0.069(0.058)$ & 0.064 & 0.077 & $0.036^{\circ}$ & $0.053^{\circ}$ \\
\hline$: 12-92: 12$ & $0.008(-0.022)$ & $0.077(0.067)$ & 0.057 & 0.074 & $-0.090^{\circ}$ & $-0.105^{\circ}$ \\
\hline $91: 12-92: 12$ & $0.068(0.062)$ & $0.077(0.067)$ & 0.052 & 0.074 & $-0.003^{*}$ & $0.006^{\circ}$ \\
\hline $91: 12-92: 12$ & $0.078(0.073)$ & $0.077(0.067)$ & 0.059 & 0.074 & 0.004 & $0.015^{\circ}$ \\
\hline $91: 12-92: 09$ & $0.023(0.019)$ & $0.033(0.020)$ & 0.050 & 0.078 & $-0.015^{\circ}$ & -0.012 \\
\hline $91: 12.92: 12$ & $0.077(0.075)$ & $0.077(0.067)$ & 0.074 & 0.074 & $-0.002^{\circ}$ & $0.008^{\circ}$ \\
\hline $22: 01-92: 12$ & $0.054(0.050)$ & $0.077(0.067)$ & 0.055 & 0.074 & $-0.016^{\circ}$ & $-0.012^{\circ}$ \\
\hline $92: 01-92: 12$ & $0.044(0.030)$ & $0.077(0.067)$ & 0.040 & 0.074 & $-0.028^{\circ}$ & $-0.043^{\circ}$ \\
\hline $92: 01-92: 12$ & $0.045(0.026)$ & $0.077(0.067)$ & 0.063 & 0.074 & $-0.045^{\circ}$ & $-0.043^{\circ}$ \\
\hline $92: 01-92: 12$ & $0.074(0.070)$ & $0.077(0.067)$ & 0.075 & 0.074 & $-0.007^{\circ}$ & $0.002^{\circ}$ \\
\hline $2: 01.92: 12$ & $0.058(0.042)$ & $0.077(0.067)$ & 0.070 & 0.074 & $-0.032^{\circ}$ & $-0.025^{\circ}$ \\
\hline $92: 11-92: 12$ & $0.272(0.232)$ & $0.3190 .259)$ & 0.042 & 0.050 & $0.032^{\circ}$ & $0.020^{\circ}$ \\
\hline & & & & & $15.6 \%$ & $\begin{array}{r}22.7 \% \\
6.8 \%\end{array}$ \\
\hline & & & & & $17.9 \%$ & $24.9 \%$ \\
\hline
\end{tabular}

Annualized returns for individual newsletters. The return after transactions costs (of $1 \%$ per round-trip) appears in parenthesis. 'Annualized return for the Standard and Poor's 500 index matched to the months for which a newsletter recommendarion is available.

Annualized standard deviation of retums.

Abnormal return a newsletter earns above that for a constant-weight cash/equity portfolio which has the same volatility as the newsletter.

'Abnormal return, above that for S\&P 500, for a constant-weight portfolio which invests in the newsletter and cash, but is leverc (or unlevered) to have the same volatility as the S\&P 500.

'The percentages at the bottom of the table exclude the equally weighted newsletter and the statistical model.

- Statistically significant at $5 \%$ level.

- Statistically significant at 10\% level.

-.. Statistically significant at $15 \%$ level 
Table 2

Direct tests of market timing and extra market timing

\begin{tabular}{|c|c|c|c|c|c|c|}
\hline \multicolumn{7}{|l|}{ Panel A: $\Delta w^{\prime}$ models } \\
\hline $\begin{array}{l}\text { Coefficient - } \\
\text { Model ! }\end{array}$ & $\delta_{2}$ & $\delta_{3}$ & $\begin{array}{c}r_{m, l+1}^{+} \\
E_{d} d r_{\bar{m}, t+d} d \\
\theta_{2}\end{array}$ & $\begin{array}{c}r_{\bar{m} t+1} \\
E_{d} r_{m, t+1}^{+} \\
\theta_{3} \\
\end{array}$ & $\begin{array}{c}r_{m, l+1}^{+} \\
\left.E_{\alpha} r_{m, l+l}^{+}\right] \\
\theta_{4}\end{array}$ & $\begin{array}{l}r_{\overline{m_{1}(+1}} \\
\left.E_{[} r_{\overline{m_{1}+1}}\right] \\
\theta_{5} \\
\end{array}$ \\
\hline $\begin{array}{l}\text { (3) Market conditions model: } \\
\text { Adj. } \mathrm{R}^{2}: \quad 0.0246 \\
\text { Equally-weighted coefficient: } \\
\text { p-value: } \\
\text { Percent positive, all letters: }\end{array}$ & $\begin{array}{l}.000059 \\
.8025 \\
46.5 \% \\
\end{array}$ & & & & & \\
\hline $\begin{array}{l}\text { (3) Market conditions, } r_{m i+1}>0 \\
\text { Adj. } R^{2}: 0.1241 \\
\text { Equally-weighted coefficient: } \\
\text { p-value: } \\
\text { Percent positive, all letters: }\end{array}$ & $\begin{array}{l}.000080 \\
.6304 \\
58.1 \% \\
\end{array}$ & & & & & \\
\hline $\begin{array}{l}\text { (3) Market conditions. } r_{m, t+1}<0 \\
\text { Adj. } R^{2}: 0.0128 \\
\text { Equally-weighted coefficient: } \\
\text { p-value: } \\
\text { Percent positive, all letters: }\end{array}$ & $\begin{array}{l}.000086 \\
.7451 \\
53.1 \% \\
\end{array}$ & & & & & \\
\hline $\begin{array}{l}\text { (4) Indicator regression: } \\
\text { p-value F-stat: } \quad 0.9982 \\
\text { Equally-weighted coefficient: } \\
\text { p-value: } \\
\text { Percent positive, all letters: }\end{array}$ & $\begin{array}{l}-.0289 \\
.9866 \\
42.5 \% \\
\end{array}$ & $\begin{array}{l}.1085 \\
.9515 \\
57.7 \% \\
\end{array}$ & & & & \\
\hline $\begin{array}{l}\text { (5) Timing model: } \\
\text { p-value F-stat: } 0.8418 \\
\text { Equally-weighted coefficient: } \\
\text { p-value: } \\
\text { Percent positive, all letters: }\end{array}$ & & & $\begin{array}{l}-1.47 \\
0.6424 \\
40.0 \%\end{array}$ & $\begin{array}{l}2.16 \\
0.3859 \\
62.6 \% \\
\end{array}$ & $\begin{array}{l}0.47 \\
0.8164 \\
48.5 \%\end{array}$ & $\begin{array}{l}-1.95 \\
0.4357 \\
50.3 \%\end{array}$ \\
\hline $\begin{array}{l}\text { (5) Timing model: } \\
\text { p-value F-stat: } 0.7804 \\
\text { Expecred volatility increase: } \\
\text { Equally-weighted coefficient: } \\
\text { p-value: } \\
\text { Percent positive, all letters } \\
\text { Expected volatility decrease: } \\
\text { Equally-weighted coefficient: } \\
\text { p-value: } \\
\text { Percent positive, all letters }\end{array}$ & & & $\begin{array}{l}-1.21 \\
0.7612 \\
36.0 \% \\
\\
\\
-2.04 \\
0.7263 \\
\mathbf{5 8 . 3 \%}\end{array}$ & $\begin{array}{l}-1.06 \\
0.7463 \\
52.6 \% \\
\\
\\
9.26 \\
0.0586 \\
69.7 \%\end{array}$ & $\begin{array}{l}-0.99 \\
0.7204 \\
54.5 \% \\
\\
\\
1.89 \\
0.4868 \\
47.0 \% \\
\end{array}$ & $\begin{array}{l}-0.60 \\
0.8642 \\
60.9 \% \\
\\
\\
-3.91 \\
0.3603 \\
37.8 \% \\
\end{array}$ \\
\hline
\end{tabular}


Table 2 (continued)

\begin{tabular}{|c|c|c|c|c|c|c|}
\hline \multicolumn{7}{|l|}{ Panel $A$ : demeaned $w$ models } \\
\hline $\begin{array}{l}\text { Coefficient - } \\
\text { Model } 1 \\
\end{array}$ & $\delta_{2}$ & $\delta_{3}$ & $\begin{array}{c}r_{m, t+1}^{+} \\
E_{d}\left[r_{m, t+1}\right] \\
\theta_{2}\end{array}$ & $\begin{array}{c}r_{\bar{m}, 1+1} \\
E_{d}\left\{r_{m, 1+1}^{+} J\right. \\
\theta_{3} \\
\end{array}$ & $\begin{array}{c}r_{m, l+1}^{+} \\
E_{\alpha} \delta r_{m, t+1}^{+} J \\
\theta_{4} \\
\end{array}$ & $\begin{array}{c}r_{\bar{m}, t+1} \\
E_{d}\left[r_{\bar{m}_{n}, t+1}\right] \\
\theta_{3}\end{array}$ \\
\hline $\begin{array}{l}\text { (3) Market conditions model: } \\
\text { Adj. } \mathrm{R}^{2}: \quad 0.0347 \\
\text { Equally-weighted coefficient: } \\
\text { p-value: } \\
\text { Percent positive, all letters: }\end{array}$ & $\begin{array}{l}-.00027 \\
.3818 \\
36.1 \% \\
\end{array}$ & & & & & \\
\hline $\begin{array}{l}\text { (3) Market conditions, } r_{m,+1}> \\
\text { Adj. } \mathrm{R}^{2}: \quad 0.1297 \\
\text { Equally-weighted coefficient: } \\
\text { p-value: } \\
\text { Percent positive, all letters: }\end{array}$ & $\begin{array}{l}.000178 \\
0.3721 \\
50.0 \% \\
\end{array}$ & & & & & \\
\hline $\begin{array}{l}\text { (3) Market conditions, } r_{m, t+1}< \\
\text { Adj. } \mathrm{R}^{2}: \quad 0.0118 \\
\text { Equally-weighted coefficient: } \\
\text { p-value: } \\
\text { Percent positive, all letters: }\end{array}$ & $\begin{array}{l}.000004 \\
0.9923 \\
49.4 \% \\
\end{array}$ & & & & & \\
\hline $\begin{array}{l}\text { (4) Indicator regression: } \\
\text { p-value F-stat: } \quad 0.7350 \\
\text { Equally-weighted coefficient: } \\
\text { p-value: } \\
\text { Percent positive, all letters: }\end{array}$ & $\begin{array}{l}1.01 \\
0.5697 \\
37.3 \% \\
\end{array}$ & $\begin{array}{l}-1.36 \\
0.5900 \\
63.2 \% \\
\end{array}$ & & & & \\
\hline $\begin{array}{l}\text { (5) Timing model: } \\
\text { p-value F-stat: } \quad 0.0011 \\
\text { Equally-weighted coefficient: } \\
\text { p-value: } \\
\text { Percent positive, all letters: }\end{array}$ & & & $\begin{array}{l}-7.61 \\
0.0116 \\
35.0 \%\end{array}$ & $\begin{array}{l}5.82 \\
0.0604 \\
73.8 \% \\
\end{array}$ & $\begin{array}{l}4.16 \\
0.0408 \\
58.2 \% \\
\end{array}$ & $\begin{array}{l}-8.55 \\
0.0092 \\
44.3 \% \\
\end{array}$ \\
\hline $\begin{array}{l}\text { (5) Timing model: } \\
\text { p-value F-stat: } 0.0067 \\
\text { Expected vo:sility increase: } \\
\text { Equally-weighted coefficient: } \\
\text { p-value: } \\
\text { Percent positive, all letters } \\
\text { Expected volatility decrease: } \\
\text { Equally-weighted coefficient: } \\
\text { p-value: } \\
\text { Percent positive, all letters }\end{array}$ & & & $\begin{array}{c}-4.64 \\
0.2890 \\
33.8 \% \\
\\
-14.38 \\
0.0308 \\
39.6 \%\end{array}$ & $\begin{array}{l}-7.06 \\
0.0595 \\
66.8 \% \\
\\
\\
3.07 \\
0.5779 \\
69.2 \%\end{array}$ & $\begin{array}{l}3.59 \\
0.2527 \\
51.8 \% \\
\\
\\
-4.71 \\
0.1291 \\
58.5 \%\end{array}$ & $\begin{array}{c}-\mathbf{5 . 7 3} \\
0.1540 \\
\mathbf{4 8 . 4 \%} \\
\\
\\
-12.65 \\
0.0099 \\
\mathbf{3 9 . 9 \%} \\
\end{array}$ \\
\hline
\end{tabular}


Coefficients for the following regressions indicate the direction of change of the investment weights (Panel A) or the demeaned level of the investment weights (Panel B) for newsletter $i$. The Panel A regressions are of the form:

Market conditions model:

$$
r_{m, t+1}=\delta_{1}+\delta_{2} \Delta w_{i s}+\delta Z_{t}+\epsilon_{i, t+1}
$$

Indicator regression:

$$
\begin{aligned}
& \Delta w_{i l}=\delta_{2} I\left(r_{m, 1+1}^{+}\right)+\delta_{3} I\left(r_{m_{1}+1}\right)+\epsilon_{i, t+l} \\
& \Delta w_{i t}=\theta_{2} I\left(r_{m, t+1}^{+} \& E_{d}\left(r_{m_{i+1}} J\right)+\theta_{3} I\left(r_{m i+1} \& E_{d}\left[r_{m, d+l}^{+} J\right)\right.\right. \\
& \theta_{d} J\left(r_{m, 1+1}^{+} \& E\left[r_{m, 1+}^{+} d\right)+\theta_{5} I\left(r_{m, 1+1} \& E_{d}\left(r_{m_{1}+d}\right)\right)+\epsilon_{i, 1+1}\right.
\end{aligned}
$$

where $r_{m,+1}$ future market return, $w_{i}$ is the investment weight in the equity market for newsletter $i$ in period $t, Z$, is a set of public information variables available at time $t, I\left(r_{m, t+1}^{+}\right)$denotes a dummy variable equal to one when the market is positive and $I\left(r_{m i+1}^{+} \& E\left\{r_{m i+l}^{+}\right]\right)$denotes an indicator dummy equal to one when the market return and the expected market return are both positive. The instrumental variables in $Z_{l}$ are the lagged excess return on the CRSP equally-weighted NYSE index, the lagged excess return on a 3-month treasury bill, the lagged Moody's Baa-Aaa yield spread, the lagged excess dividend yield on the S\&P 500 index, and a January dummy variable.

The panel $B$ regressions replace $\Delta w_{i j}$ with demeaned values of $w_{i j}$. The last row of each panel subsets each of the variables in the timing model for expected increases or decreases in volatility. The coefficients in the last row which are shown in bold are unambiguous, in the sense that the expected change in volatility and the realized market return give reinforcing implications about optimal investment weights. The reported coefficients, p-values, and adjusted $R^{2} s$ are for the average newsletter. F-statistic p-values are shown for the last three regressions in each panel because they have no intercept and $\mathrm{R}^{2}$ does not have its usual interpretation. Also repored are the average number of positive coefficients across the individual newsletter regressions. 
Table 3

Persistence in performance

\begin{tabular}{|c|c|c|c|}
\hline Panel A: & $\begin{array}{l}\text { Persistence } \\
\text { regressions }\end{array}$ & & \\
\hline $\begin{array}{l}\text { Independent } \\
\text { variable - } \\
\text { Dependent } \\
\text { variable } 1\end{array}$ & $\begin{array}{l}\text { Return: } \\
\text { 1980-1984 }\end{array}$ & $\begin{array}{l}\text { Return: } \\
\text { 1985-1988 }\end{array}$ & $\begin{array}{l}\text { Pooled Return: } \\
\text { 1980-1984, } \\
1985-1988\end{array}$ \\
\hline $\begin{array}{l}\text { Return: } \\
\text { 1985-1988 }\end{array}$ & $\begin{array}{lr}\text { coefficient: } & 0.8309 \\
\text { p-value: } & 0.0001 \\
\text { Adj. } R^{2}: & 0.4781 \\
\text { Observations: } & 14 \\
\end{array}$ & & \\
\hline $\begin{array}{l}\text { Return: } \\
\text { 1989-1992 }\end{array}$ & & $\begin{array}{lr}\text { coefficient: } & 0.6240 \\
\text { p-value: } & 0.0001 \\
\text { Adj. R }{ }^{2}: & 0.4552 \\
\text { Observations: } & 32 \\
\end{array}$ & \\
\hline $\begin{array}{l}\text { Pooled renurn: } \\
\text { 1985-1988, } \\
1989-1992\end{array}$ & & & $\begin{array}{lr}\text { coefficient: } & 0.6000 \\
\text { p-value: } & 0.0001 \\
\text { Adj. } R^{2}: & 0.3712 \\
\text { Observations: } \quad 46\end{array}$ \\
\hline
\end{tabular}


Table 3 (continued)

Panel B: Persistence probabilities

Positive abnormal return:

$\operatorname{Pr}\left(\right.$ Measure $2_{\mathrm{r}}>0 \mid$ Measure $\left._{\mathrm{r} \cdot \mathrm{l}}>0\right)=0.373$

319 newsletter-year observations meet the condition that Measure $2_{\mathrm{i}-1}>0$

$\operatorname{Pr}\left(\right.$ Measure $2_{1}>0 \mid$ Measure $_{1 \cdot 1}$ and Measure $\left.2_{1 \cdot 2}>0\right)=0.476$

103 newsletter-year observations meet the condition that Measure2 $2_{1-1}$ and Measure $2_{1.2}>0$

$\operatorname{Pr}\left(\right.$ Measure $2_{\mathrm{t}}>0 \mid$ Measure $_{\mathrm{t}-\mathrm{t}}$ through Measure $\left.2_{\mathrm{t}-3}>0, \mathrm{f}\right)=0.452$

31 newsletter-year observations meet the condition that Measure2 $2_{t-1}$ through Measure $2_{1.3}>0$

$\operatorname{Pr}\left(\right.$ Measure2 $_{1}>0 \mid$ Measure2 $_{t-1}$ through Measure2 $\left.{ }_{1-4}>0\right)=0.545$

11 newsletter-year observations meet the condition that Measure $2_{1-1}$ through Measure $2_{1-4}>0$

Negative abnormal return:

$\operatorname{Pr}\left(\right.$ Measure $_{1}<0 \mid$ Measure $\left._{1-1}<0\right)=0.676$

624 newsletter-year observations meet the condition that Measure $2_{t-1}<0$

$\operatorname{Pr}\left(\right.$ Measure $2_{1}<0 \mid$ Measure $2_{1-1}$ and Measure $\left.2_{1-2}<0\right)=0.665$

331 newsletter-year observations meet the condition that Measure $2_{1.1}<0$ and Measure $2_{1.2}<0$

$\operatorname{Pr}\left(\right.$ Measure $2_{1}<0 \mid$ Measure $2_{1-1}$ through Measure $\left.2_{1-3}<0,\right)=0.711$

166 newsletter-year observations meet the condition that Measure $2_{\mathrm{r}-\mathrm{l}}$ through Measure $2_{\mathrm{l} \cdot \mathrm{3}}<0$

$\operatorname{Pr}\left(\right.$ Measure $2_{t}<0 \mid$ Measure $2_{t-1}$ through Measure $\left.2_{t-4}<0\right)=0.762$

101 newsletter-year observations meet the condition that Measure $_{t-1}$ through Measure $2_{t-4}<0$

Panel A shows results for a cross-sectional regression of "four-year" abnormal returns, represented by the second nonparametric performance measure, on lagged four-year returns. To qualify as a fouryear return, a monthly return series must be cumulated over at least 36 months in the four-year period listed. The 1980-1984 period can contain as many as 54 monthly returns.

Panel B presents the probability that the second nonparametric performance measure is positive, given that it was positive in the previous period(s), and likewise for negative abnormal returns. Measure2 is the increast in return over the S\&P 500 return obtained by levering (or unlevering) a newsletter strategy by increasing (or decreasing) the portion of the investment which is long the equity market, so that the strategy's volatility is identical to that for the S\&P 500 over the same investment period. 
Table 4

Evaluating forecasts of the market return

\begin{tabular}{|c|c|c|c|c|c|c|}
\hline \multicolumn{7}{|l|}{$\begin{array}{l}\text { Comparing actual } r_{m, t+1} \\
\text { to forecast of } r_{m, 1+1}\end{array}$} \\
\hline $\begin{array}{l}\text { Summary statistics - } \\
\text { Forecasting model }\end{array}$ & $\begin{array}{l}\text { Adj. } \mathrm{R}^{2} \text { for } \\
\text { regression } \\
r_{m, 1+1} \text { on } \\
\mathrm{E}_{(}\left(r_{m, 1+1}\right)^{2}\end{array}$ & $\begin{array}{l}\text { Mean } \\
\text { square } \\
\text { error }\end{array}$ & $\begin{array}{l}\text { Mean } \\
\text { abs. } \\
\text { errorb }\end{array}$ & $\begin{array}{l}\text { Correct } \\
\text { directione }\end{array}$ & $\begin{array}{l}\text { Average } \\
\text { monthly } \\
\text { retum, } \\
\text { forecast }\end{array}$ & $\begin{array}{l}\text { Average } \\
\text { monthly } \\
\text { return, } \\
\text { actuale }^{\circ}\end{array}$ \\
\hline 1980-1992 sample (150 Obs.) & & & & & & 0.0134 \\
\hline Statistical model: & 0.0097 & 0.0022 & 0.0343 & $59.6 \%$ & 0.0048 & \\
\hline Mean: & 0.0118 & 0.0022 & 0.0340 & $62.7 \%$ & 0.0194 & \\
\hline Median: & 0.0153 & 0.0022 & 0.0340 & $62.7 \%$ & 0.0188 & \\
\hline Weighted average: & 0.0111 & 0.0021 & 0.0342 & $62.0 \%$ & 0.0137 & \\
\hline $\begin{array}{l}\text { 1980-1992 sample, } \\
\text { excluding Oct87 (1+9 Obs.) }\end{array}$ & & & & & & 0.0149 \\
\hline Statistical model: & 0.0279 & 0.0019 & 0.0330 & $60.0 \%$ & 0.0047 & \\
\hline Mean: & -0.0068 & 0.0018 & 0.0325 & $63.1 \%$ & 0.0192 & \\
\hline Median: & -0.0066 & 0.0018 & 0.0325 & $63.1 \%$ & 0.0186 & \\
\hline Weighted average: & -0.0048 & 0.0018 & 0.0328 & $62.4 \%$ & 0.0137 & \\
\hline 1987-1992 sample (72 Obs.) & & & & & & 0.0123 \\
\hline Statistical model: & -0.0134 & 0.0026 & 0.0351 & $63.9 \%$ & 0.0038 & \\
\hline Mean: & 0.0151 & 0.0026 & 0.0344 & $63.9 \%$ & 0.0204 & \\
\hline Median: & 0.0210 & 0.0026 & 0.0344 & $63.9 \%$ & 0.0198 & \\
\hline Weighted average: & 0.0039 & 0.0025 & 0.0351 & $63.9 \%$ & 0.0141 & \\
\hline $\begin{array}{l}\text { 1987-1992 sample, } \\
\text { excluding Oct87 ( } 71 \text { Obs.) }\end{array}$ & & & & & & 0.0155 \\
\hline Statistical model: & 0.0147 & 0.0018 & 0.0322 & $64.8 \%$ & 0.0035 & \\
\hline Mean: & -0.0136 & 0.0017 & 0.0313 & $64.8 \%$ & 0.0201 & \\
\hline Median: & -0.0143 & 0.0017 & 0.0313 & $64.8 \%$ & 0.0195 & \\
\hline Weighted average: & -0.0145 & 0.0017 & 0.0322 & $64.8 \%$ & 0.0140 & \\
\hline
\end{tabular}

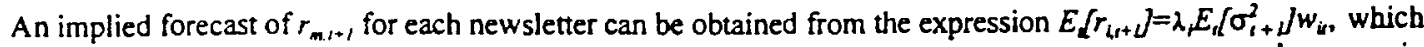
is derived for agents with negative exponential utility. $E_{L}\left[r_{i, i+d}\right]$ is the expected excess rerum on the assets in a portfolio formed by following newsletter $i$ 's recommendations, $\lambda_{i}$ is the newsletter-specific coefficient of relative risk aversion, $\sigma_{t+1}^{2}$ is the variance of the market and $w_{4}$ are the newsletter-specific weights. Table 4 presents the restits of comparing these forecasts to the actual S\&P 500 monthly return. Results are shown for the mean forecast, the median forecast, a weighted average with weights which are the inverse of the previous period's squared forecast error, and a statistical model. The statistical model predicts the market return using five instruments: the lagged excess rerum on the CRSP equally-weighted NYSE index, the lagged excess return 
on a 3-month treasury bill, the lagged Moody's Baa-Aaa yield spread, the lagged excess dividend yield on the S\&P 500 index, and a January dummy variable. The bottom two rows of results are out-of-sample in the sense that the statistical model was originally fit to data through December 1986.

'The adjusted-R: of a regression of the actual monthly S\&P 500 on the forecasted return.

'Mean absolute forecast error.

The percentage of forecasts which were positive when the market was positive or negative when the market was negative.

'The average monthly forecast of $r_{m}$ as implied by investment newsletters.

The average monthly S\&P 500 return. 
Table 5

Correlatiou and causality of forecast dispersion, market volatility, and trading activity.

\begin{tabular}{|c|c|c|c|}
\hline \multicolumn{2}{|l|}{ Panel A: } & \multicolumn{2}{|l|}{$\begin{array}{l}\text { Contemporaneous } \\
\text { correlations }\end{array}$} \\
\hline $\begin{array}{l}\text { First } \\
\text { difference } \\
\text { form }\end{array}$ & $\begin{array}{l}\text { Historical } \\
\text { volatility }\end{array}$ & $\begin{array}{l}\text { Implied } \\
\text { volatilityc }\end{array}$ & $\begin{array}{l}\text { Volume per } \\
\text { share }^{d}\end{array}$ \\
\hline Dispersion ${ }^{3}$ & $\begin{array}{ll}\text { correlation: } & 0.0436 \\
\text { p-value: } & 0.6232\end{array}$ & $\begin{array}{ll}\text { correlation: } & 0.1212 \\
\text { p-value: } & 0.0599\end{array}$ & $\begin{array}{ll}\text { correlation: } & 0.0566 \\
\text { p-value: } \quad 0.5169\end{array}$ \\
\hline $\begin{array}{l}\text { Historical } \\
\text { volatility }\end{array}$ & Observations: 148 & $\begin{array}{lr}\text { Observations: } & 82 \\
\text { correlation: } & 0.7783 \\
\text { p-value: } \quad 0.0001 \\
\text { Observations: } \quad 83\end{array}$ & $\begin{array}{lr}\text { Observations: } & 149 \\
\text { correlation: } & 0.6481 \\
\text { p-value: } \quad 0.0002 \\
\text { Observations: } \quad 149\end{array}$ \\
\hline $\begin{array}{l}\text { Implied } \\
\text { volatility }\end{array}$ & & & $\begin{array}{lr}\text { correlation: } & 0.6246 \\
\text { p-value: } \quad 0.0048 \\
\text { Observations: } \quad 83\end{array}$ \\
\hline
\end{tabular}

\begin{tabular}{|c|c|c|c|}
\hline \multicolumn{2}{|l|}{ Panel B: } & \multicolumn{2}{|l|}{$\begin{array}{l}\text { Contemporaneous } \\
\text { correlations }\end{array}$} \\
\hline $\begin{array}{l}\text { Level } \\
\text { values }\end{array}$ & $\begin{array}{l}\text { Historical } \\
\text { volatility }\end{array}$ & $\begin{array}{l}\text { Implied } \\
\text { volatility }\end{array}$ & $\begin{array}{l}\text { Volume per } \\
\text { share }\end{array}$ \\
\hline Dispersion & $\begin{array}{lr}\text { correlation: } & 0.5356 \\
\text { p-value: } \quad 0.0001 \\
\text { Observations: } \quad 149\end{array}$ & $\begin{array}{lr}\text { correlation: } & 0.7638 \\
\text { p-value: } \quad 0.0001 \\
\text { Observations: } \quad 83\end{array}$ & $\begin{array}{lc}\text { correlation: } & 0.2642 \\
\text { p-value: } \quad & 0.0302 \\
\text { Observations: } \quad & 150\end{array}$ \\
\hline $\begin{array}{l}\text { Historical } \\
\text { volatility }\end{array}$ & & $\begin{array}{lr}\text { correlation: } & 0.8298 \\
\text { p-value: } \quad 0.0001 \\
\text { Observations: } \quad 84\end{array}$ & $\begin{array}{ll}\text { correlation: } & 0.4068 \\
\text { p-value: } \quad 0.0780 \\
\text { Observations: } \quad 150\end{array}$ \\
\hline $\begin{array}{l}\text { Implied } \\
\text { volatility }\end{array}$ & & & $\begin{array}{lr}\text { correlation: } & 0.5451 \\
\text { p-value: } \quad 0.0037 \\
\text { Observations: } \quad 84\end{array}$ \\
\hline $\begin{array}{l}\text { First abs. } \\
\text { difft } r t \text { nce: } \\
\mathrm{E}\left(r_{m, t+1}\right)^{e}\end{array}$ & & & $\begin{array}{ll}\text { correlation: } & 0.3783 \\
\text { p-value: } \quad 0.0001 \\
\text { Observations: } \quad 149\end{array}$ \\
\hline
\end{tabular}


Table 5 (continued)

\begin{tabular}{|c|c|c|c|c|}
\hline Panel C: & $G_{1}$ anlger causality & F-statistics & & \\
\hline $\begin{array}{l}\text { Column - } \\
\text { causes } \\
\text { Row ! }\end{array}$ & Dispersion & $\begin{array}{l}\text { Historical } \\
\text { volatility }\end{array}$ & $\begin{array}{l}\text { Implied } \\
\text { volatility }\end{array}$ & $\begin{array}{l}\text { Volume } \\
\text { per share }\end{array}$ \\
\hline Dispersion & & $\begin{array}{ll}\text { w/ Oct87: } & 1.07 \\
\text { w/o Oct87: } & 0.61 \\
\end{array}$ & $\begin{array}{l}\text { w/ Oct87: } 2.77^{\circ} \\
\text { w/o Oct87: } 1.19\end{array}$ & $\begin{array}{l}\text { w/ Oct87: } 1.02 \\
\text { w/o Oct87: } 0.55\end{array}$ \\
\hline $\begin{array}{l}\text { Historical } \\
\text { volatility }\end{array}$ & $\begin{array}{l}\text { w/ Oct87: } 51.37^{\circ} \\
\text { w/o Oct87: } 5.89^{\circ}\end{array}$ & & & $\begin{array}{ll}\text { w/Oct87: } & 0.84 \\
w / 0 \text { Oct } 87: & 0.34\end{array}$ \\
\hline $\begin{array}{l}\text { Implied } \\
\text { volatility: }\end{array}$ & $\begin{array}{l}\text { w/ Oct87: } 46.06^{\circ} \\
\text { w/o Oct87: } 4.51^{\circ}\end{array}$ & & & $\begin{array}{ll}\text { w/ Oct87: } & 2.90 \\
\text { w/o Oct87: } & 0.95\end{array}$ \\
\hline $\begin{array}{l}\text { Volume } \\
\text { per share }\end{array}$ & $\begin{array}{l}\text { w/ Oct87: } 17.34^{\circ} \\
\text { w/o Oct87: } 5.07^{\circ}\end{array}$ & $\begin{array}{l}\text { w/ Oct87: } 6.64^{\circ} \\
\text { w/o Oct87: } 6.26^{\circ}\end{array}$ & $\begin{array}{l}\text { w/ Oct87: } 4.82^{\circ} \\
\text { w/o Oct87: } 4.63^{\circ}\end{array}$ & \\
\hline
\end{tabular}

\begin{tabular}{|l|l|l|l|l|}
\hline Panel D: & \multicolumn{3}{|c|}{ Exogenous shocks } \\
\hline Shocked & Period & Dispersion & $\begin{array}{l}\text { Historical } \\
\text { volatility, }\end{array}$ & $\begin{array}{l}\text { Volume } \\
\text { per share }\end{array}$ \\
variable- & & & & \\
Dependent & & & & \\
variable 1 & & & 5.3 & -1.0 \\
\hline Dispersion & $t+1$ & 37.5 & 3.5 & 1.9 \\
& $t+2$ & 31.0 & 3.1 & 3.1 \\
\hline & $t+3$ & 32.7 & 1.0 & 0.8 \\
\hline Historical & $t+1$ & 80.0 & 7.3 & 8.1 \\
volatility & $t+2$ & 13.6 & 23.1 & 4.8 \\
\hline Volume & $t+3$ & 11.1 & -8.1 & 10.9 \\
per share & $t+1$ & 14.7 & -1.1 & 16.2 \\
& $t+3$ & 1.3 & -2.5 & 21.8 \\
\hline
\end{tabular}

Panels $A$ and $B$ contain the contemporaneous correlations of monthly observations for the listed variables. Panel A presents the results for first differences of the data while Panel B presents results for level values. Panel C displays F-statistics which can be used to infer which of the variables cause the others, in the Granger sense. The variables in the first two and last two rows of Panel $C$ are dependent variables in an unrestricted regression which has twelve explanatory variables: three lags each of dispersion, historical volatility, volume per share, and the first absolute difference of the mean forecast. The regressions involving implied volatility substitute lags of implied volatility in place of lags of historical volatility. The 
F-statistic tests the difference in the sum of squared errors between the unrestricted regression and a restricted regression which drops the three lags of the candidate causal variable. A significant F-statistic implies that the candidate variable Granger-causes the dependent variable. Results for Panel C are shown both with and $x$ ichout the October 1987 data point.

Panel D shows the cumulative percentage increase in the variables listed in the first column for one, two and three periods ahead resulting from a shock to the variables listed in the top row. The shock takes the form of a one standard deviation increase in the current period value of the shocked variable. The coefficients used to gauge the effect of the shocks in Panel D are obtained from the unrestricted regressions run for Panel C. The results (not shown) of repeating the analysis using implied volatility in Panel D. rather than historical volatility, are not substantially changed.

'Dispersion measures the standard deviation over the cross-section of implied market return forecasts across non-missing observations for a sample of 237 investment newsletters for each month in the period 1980:07 through 1992:12.

"Monthly historical volatility is obtained by summing squared daily returns plus two times the autocovariance for daily S\&P 500 returns.

Implied volatility is for the S\&P 100 index and exists starting in January 1986.

'Volume per share is monthly NYSE volume for all shares divided by total number of shares outstanding.

'The absolute value of the first difference of the mean forecast is based on the average of the implied market forecasts made by the newsletters.

- indicates significant at $\alpha=0.05$ 
Figure 1

Mean-standard deviation analysis

A: All years, all newsletters

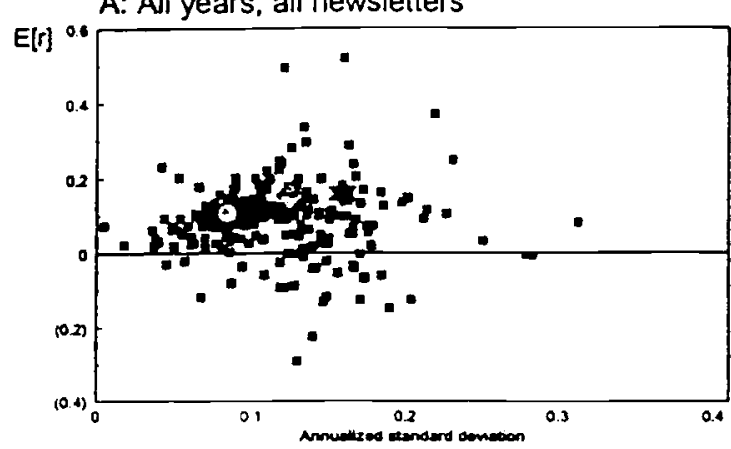

C: Post-1986, all newsletters

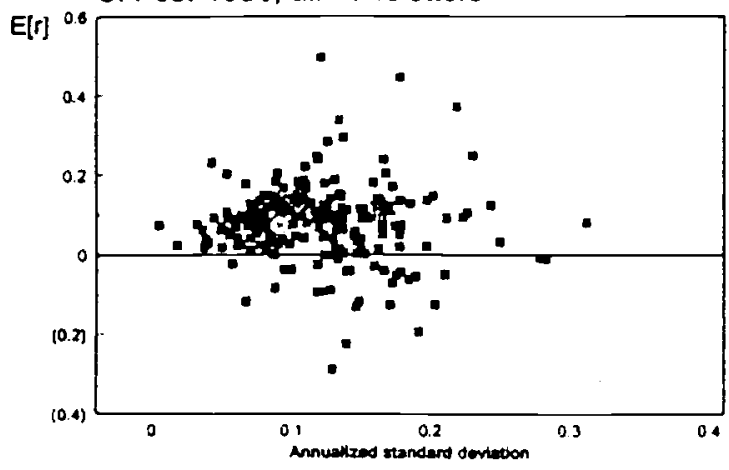

B: All years, letters existing more than 4 years

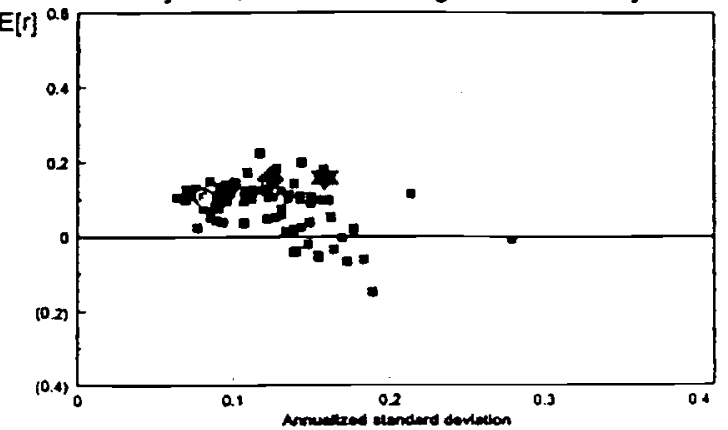

D: Post-1986, letters existing more than 4 years

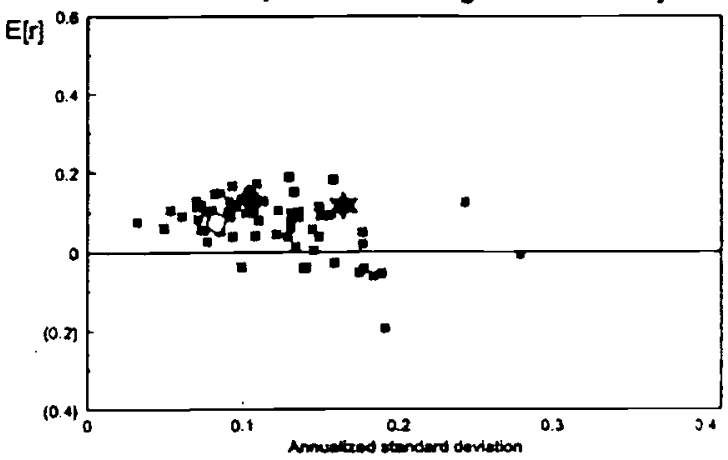

Figure ! concains scaucr plots for mean annualized renurns versus annualized standard deviations. Data are presented for newsletters as well as an equally-weighted newsletter portfolio (circle), a statistical model (diamond) and the S\&P 500 index (star). Panels $A$ and $C$ contain all newsletters; panels B and D contain newsletters which have provided recommendations for at least 49 months. Panels $A$ and $B$ have results calculated over the period 1980:06-1992:12. for months in which a newslenter makes a recommendation. Panels $C$ and $D$ use data from 1987:01-1992:12, which is entirely out of sample for the statistical model. 
Figure 2

Measuring newsletter performance

A: Measure 1, all newsletters

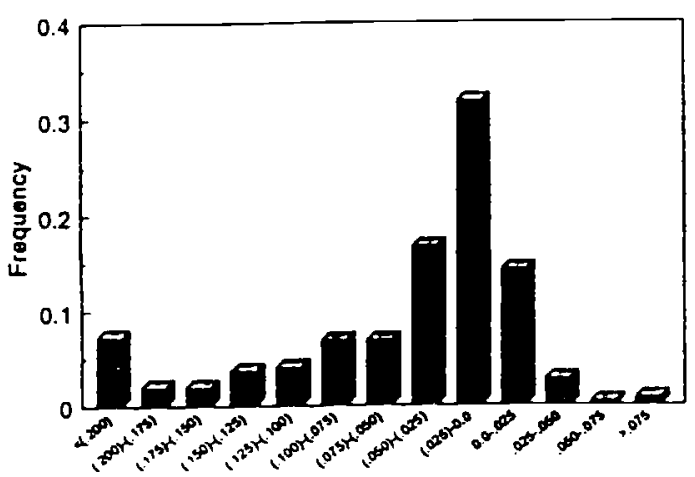

C: Measure 1 , letters existing $>4$ years

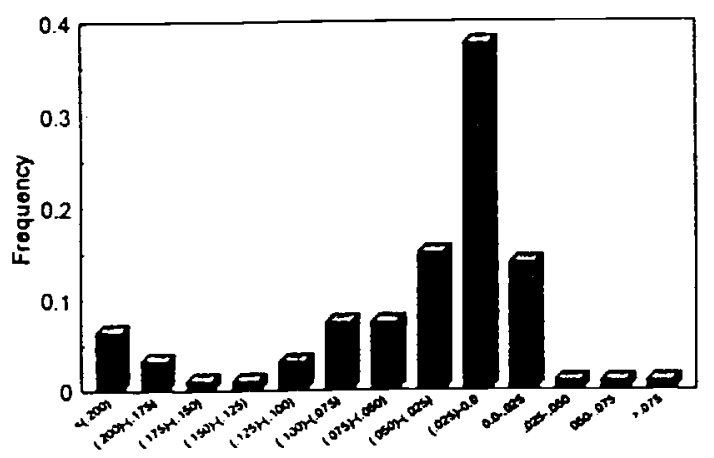

B: Measure 2, all newsletters

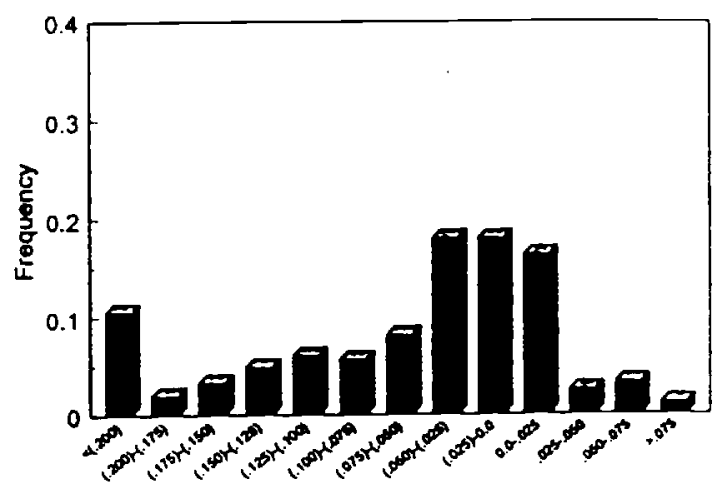

$\mathrm{D}$ : Measure 2 , letters existing $>4$ years

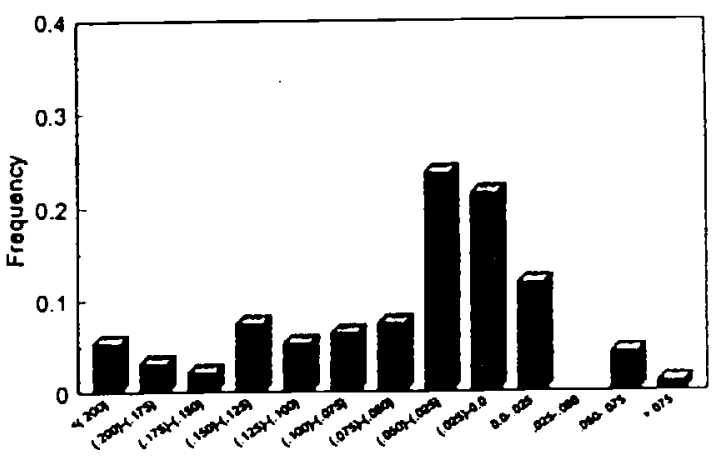

Figure 2 shows the distributions of two surnmary measures of newsletter performance. Measure 1 is the extra renurn a newsletter earns above that for a constant-weight cash/equity portfolio which has the same volatility as the newsletter. Measure 2 is the extra return, above that for the S\&P 500 index, for a constant-weight portolio which invests in the newsletter and cash, but is levered (or unievered) to achieve the same volatility as the S\&P 500 index. Panels A and B of Figure 2 contain data on all newsletters; panels $C$ and $D$ contain data for newsletters which have provided recommendations for at least 49 months. 
Figure 3: Market Timing

Panel A: $\Delta w$ model
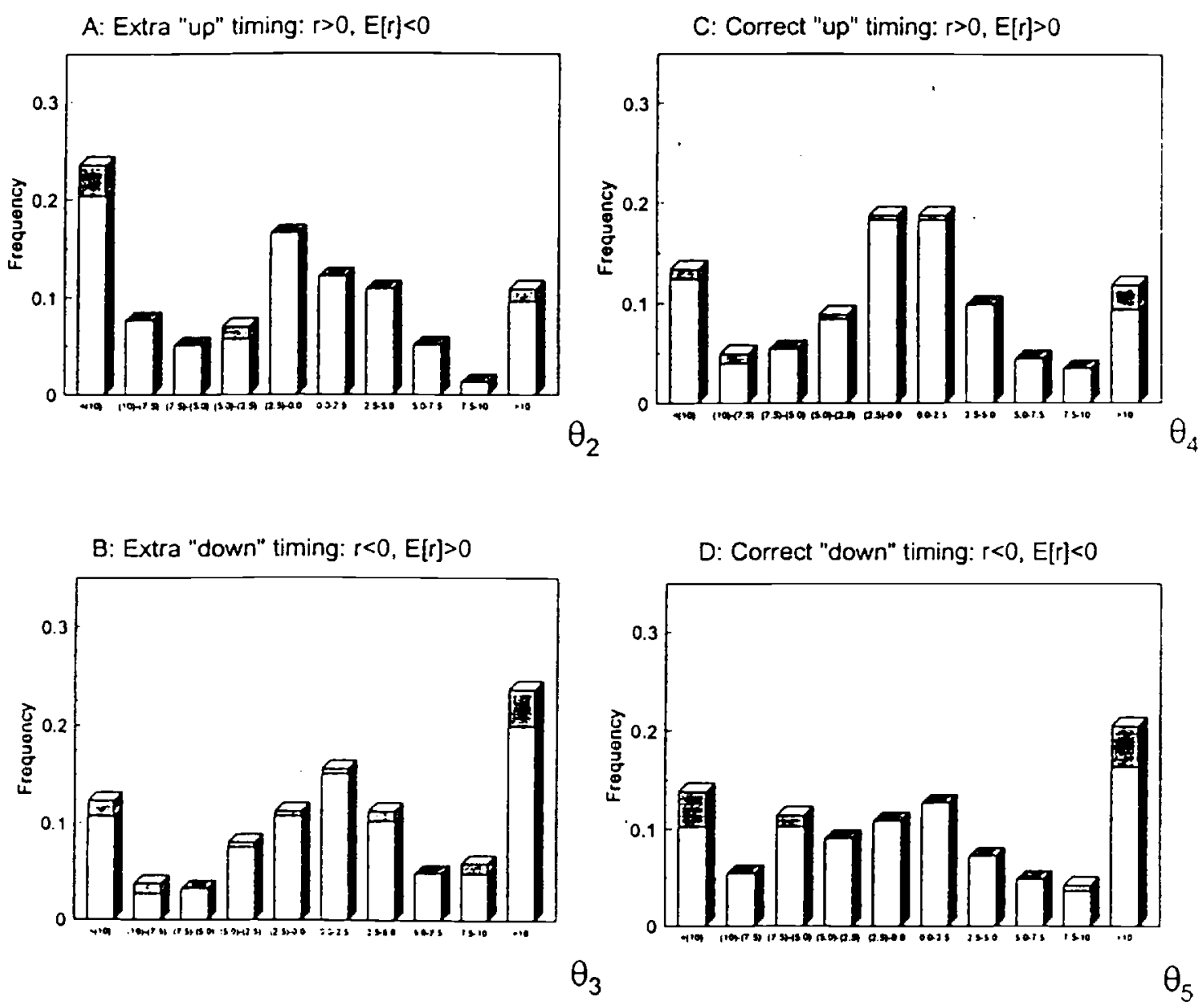
Figure 3: Market Timing

Panel B: demeaned w model

E: Extra "up" timing: $>0, E[r]<0$

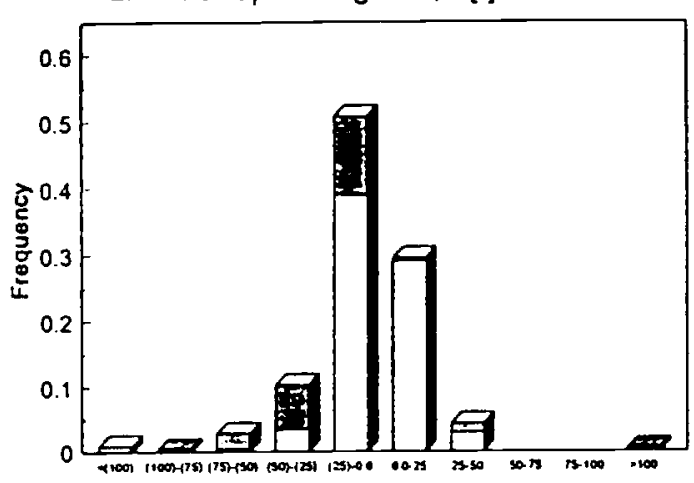

G: Correct "up" timing: $r>0, E[r]>0$

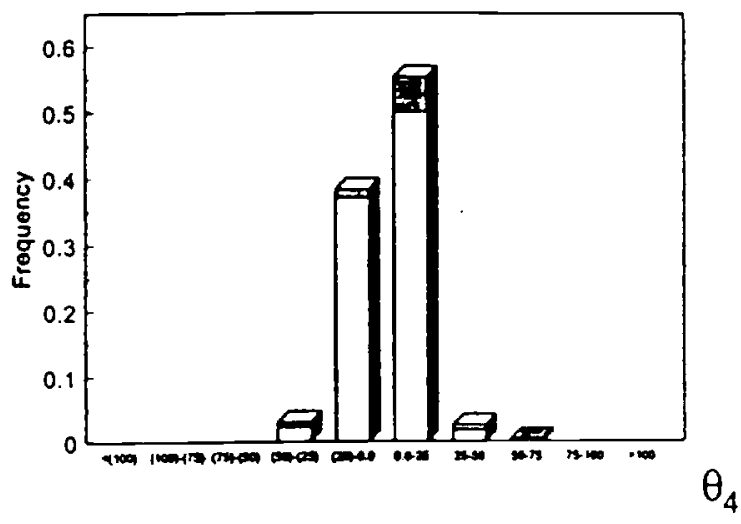

$F$ : Extra "down" timing: $r<0, E[r]>0$

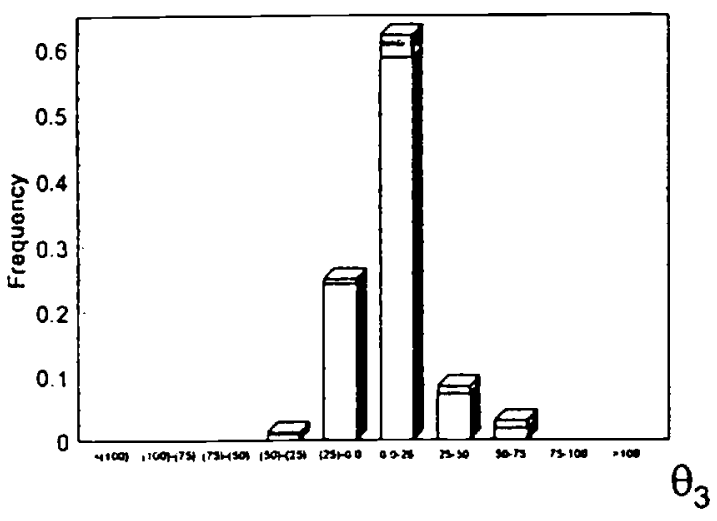

$\mathrm{H}$ : Correct "down" timing: $r<0, \mathrm{E}[\mathrm{r}]<0$

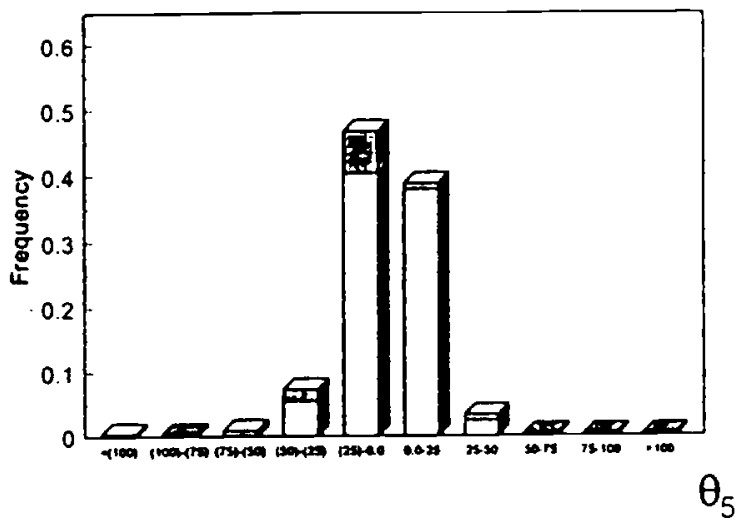

Panel A of Figure 3 presents the distribution of coefficients, across individual newsletter regressions, for the timing model:

Timing Model:

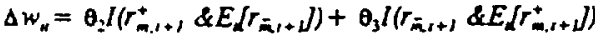

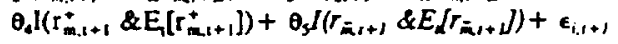

where $w_{\mathrm{a}}$ is the investment weight in the equity market for newsletter $i$ in period $t$ and $l\left(r_{m, 1+1}^{+} \& E_{d}\left(r_{m, 1+1}^{+} l\right)\right.$ denotes an indicator dummy equal to one when the market return and the expected market retum are both positive. The Panel B regressions replace $\Delta w_{i}$ with the demeaned level of $w_{i}$. The shaded portion at the top of each bar represents the frequency of coefficients which are significantly different from zero at the $10 \%$ level. Positive values of $\theta_{2}$ and $\theta_{4}$ indicale superior performance as do negative values of $\theta_{1}$ and $\theta$. 


\section{Figure 4}

Analysis of performance persistence
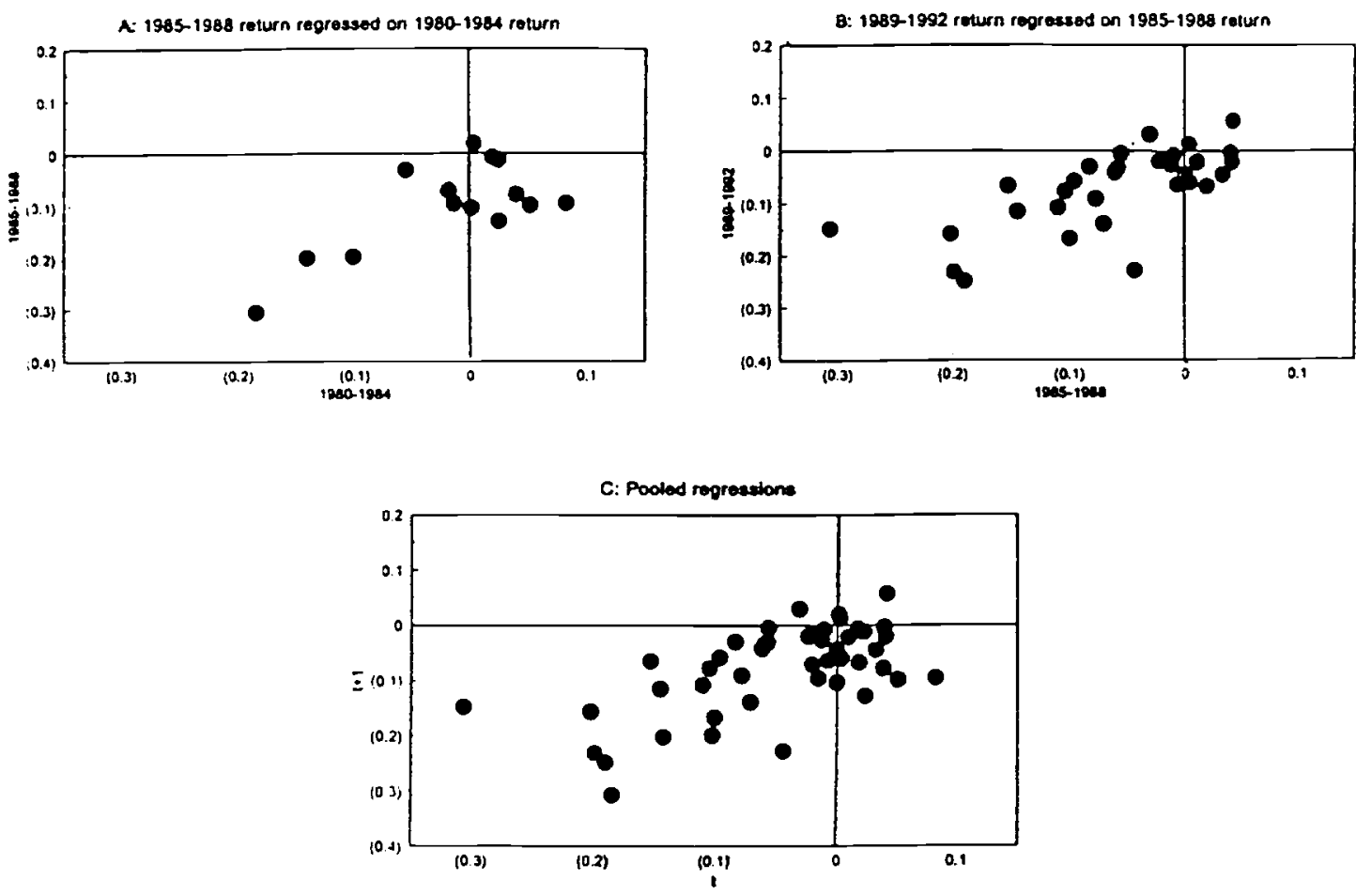

Figure 4 shows scaners of the cross-section of "four-year" abnormal renurns (verical axis) and lagged four-year abnormal renus (borizontal axis), where measure $\mathbf{2}$ is used to define abnormal renurn. To qualify as a fouryear renurn, a monthly recurn series must be cumulated over at least 36 months in the four-year period listed. The 1980-1984 period can contain as many as 54 monthly rerums. 


\section{Figure 5}

Distribution of the newsletters' implied coefficients of relative risk aversion

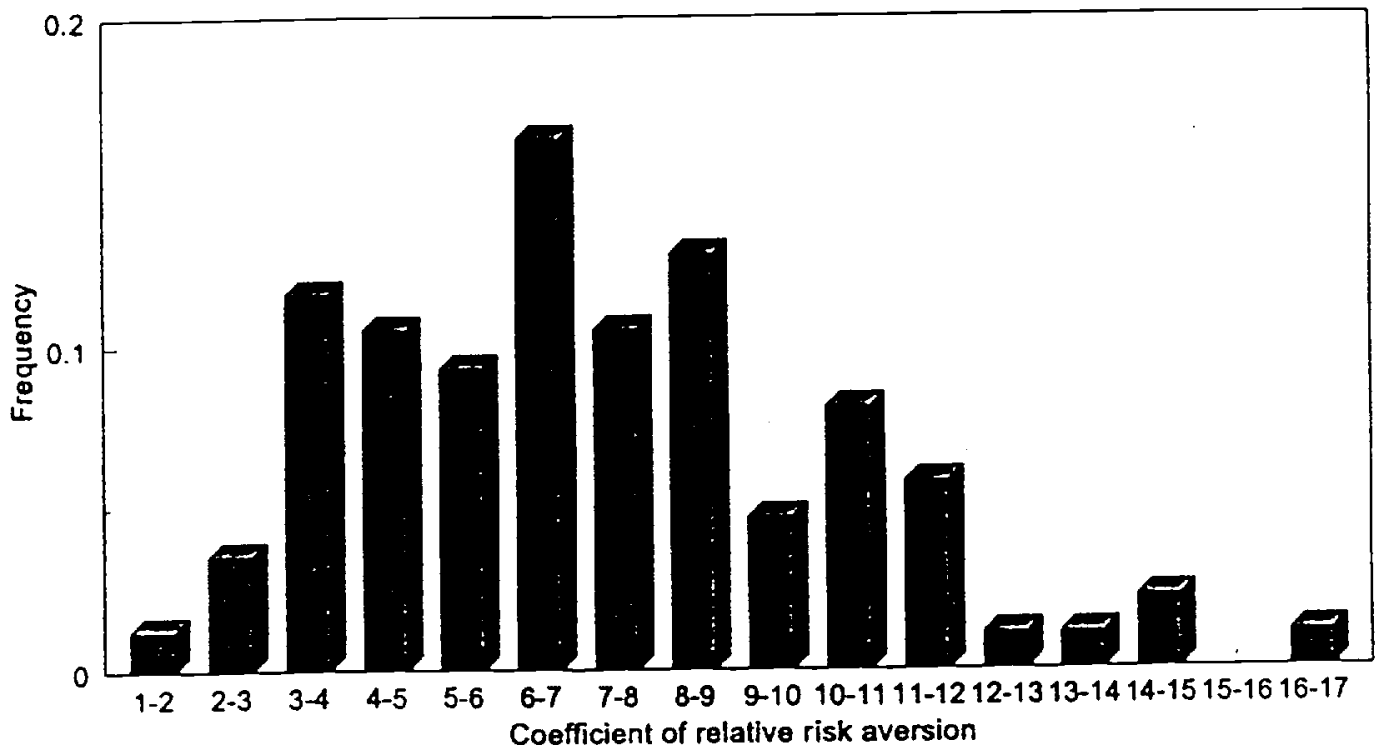

Figure $S$ presents the distribution of the coefficient of relative risk aversion, $\lambda_{i}$, for each newslener as estimated from $E[r]=2,(\operatorname{var}\{r\}-\operatorname{var}[E\{r, Z\}]) w_{\text {, }}$ which is derived for ageats with negative exponencial utility. $E[r]$ is the expected excess retum on the assets in a portfolio formed by following newsleater $i$ 's recommendations. $\lambda_{1}$ is the newsletter-specific coefficient of relative risk aversion, $\Sigma$ is the variance of the market and $w_{1}$ are the newsletrer-specific weights. 